\title{
Basement Membrane Defects in Genetic Kidney Diseases
}

\author{
Christine Chew ${ }^{1}$ and Rachel Lennon ${ }^{1,2 *}$ \\ ${ }^{1}$ Faculty of Biology Medicine and Health, Wellcome Trust Centre for Cell-Matrix Research, Division of Cell Matrix Biology, \\ School of Biological Sciences, University of Manchester, Manchester, United Kingdom, ${ }^{2}$ Department of Paediatric \\ Nephrology, Royal Manchester Children's Hospital, Central Manchester University Hospitals NHS Foundation Trust, \\ Manchester Academic Health Science Centre, Manchester, United Kingdom
}

\section{OPEN ACCESS}

Edited by:

Max Christoph Liebau, Universitätsklinikum Köln, Germany

Reviewed by:

Kimberly Jean Reidy, Children's Hospital at Montefiore/ Albert Einstein College of Medicine,

United States

Francois Cachat,

University Hospital of Bern,

Switzerland

Silviu Grisaru,

University of Calgary, Canada

*Correspondence:

Rachel Lennon

rachel.lennon@manchester.ac.uk

Specialty section:

This article was submitted to

Pediatric Nephrology,

a section of the journal

Frontiers in Pediatrics

Received: 08 October 2017 Accepted: 11 January 2018

Published: 29 January 2018

Citation:

Chew C and Lennon R (2018) Basement Membrane Defects in Genetic Kidney Diseases.

Front. Pediatr. 6:11.

doi: 10.3389/fped.2018.00011
The glomerular basement membrane (GBM) is a specialized structure with a significant role in maintaining the glomerular filtration barrier. This GBM is formed from the fusion of two basement membranes during development and its function in the filtration barrier is achieved by key extracellular matrix components including type IV collagen, laminins, nidogens, and heparan sulfate proteoglycans. The characteristics of specific matrix isoforms such as laminin-521 ( $\alpha 5 \beta 2 \gamma 1)$ and the $\alpha 3 \alpha 4 \alpha 5$ chain of type IV collagen are essential for the formation of a mature GBM and the restricted tissue distribution of these isoforms makes the GBM a unique structure. Detailed investigation of the GBM has been driven by the identification of inherited abnormalities in matrix proteins and the need to understand pathogenic mechanisms causing severe glomerular disease. A well-described hereditary GBM disease is Alport syndrome, associated with a progressive glomerular disease, hearing loss, and lens defects due to mutations in the genes COLAA3, COL4A4, or COL4A5. Other proteins associated with inherited diseases of the GBM include laminin $\beta 2$ in Pierson syndrome and $L M X 1 B$ in nail patella syndrome. The knowledge of these genetic mutations associated with GBM defects has enhanced our understanding of cell-matrix signaling pathways affected in glomerular disease. This review will address current knowledge of GBM-associated abnormalities and related signaling pathways, as well as discussing the advances toward disease-targeted therapies for patients with glomerular disease.

Keywords: basement membrane, glomerulus, Alport syndrome, genetic variation, collagen IV, Pierson syndrome

\section{INTRODUCTION}

The glomerular basement membrane (GBM) is an integral component of the glomerular filtration barrier; an important and highly complex capillary wall that is exposed to mechanical forces driven by capillary hydrostatic pressure. This barrier is permeable to water and small molecules, and selectively withholds cells and macromolecules such as albumin in the circulation (1). During glomerular development, the assembly of endothelial and podocyte layers generates the filtration barrier (2). The GBM separates endothelial cells and podocytes, and it represents a specialized extracellular matrix (ECM), which maintains barrier function (Figure 1). The GBM is formed during glomerulogenesis and is maintained by secreted components from both podocytes and endothelial cells (3-5). The mature, human GBM is relatively thick in comparison to other basement membranes and measures between 300 and $350 \mathrm{~nm}(4,6)$. In addition to the cells of the filtration barrier, mesangial 


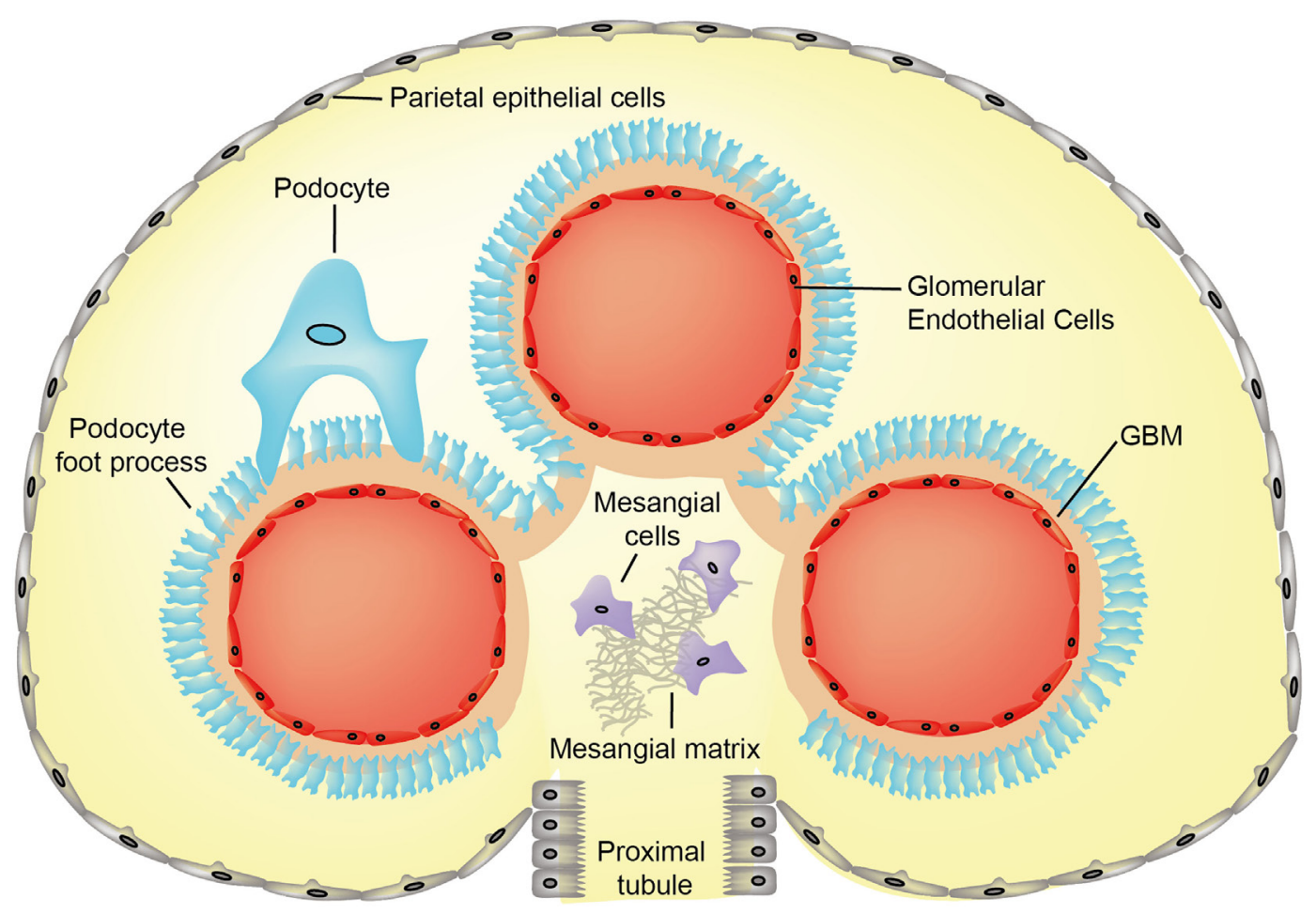

FIGURE 1 | Cross-section image of normal glomerulus showing cellular and extracellular matrix compartments. Abbreviation: GBM, glomerular basement membrane.

cells (between adjacent capillary loops) and the parietal epithelial cells of Bowman's capsule are necessary for maintaining intact glomerular function.

The fusion of podocyte and endothelial basement membranes during the development of the GBM creates an intricate meshwork containing laminins, type IV collagen, nidogen, and heparan sulfate proteoglycans (HSPGs) (7-10). Our recent mass spectrometry-based proteomic analysis of human glomerular ECM in vivo revealed a more complex composition of 144 structural and regulatory matrix proteins supporting the unique organelle structure of the glomerulus (11). Not surprisingly collagen (types I, IV, and VI), and laminin isoforms were identified as the most abundant components (11). The secretion of matrix molecules into the GBM is likely to be facilitated by cross talk between podocytes and endothelial cells. Indeed, the proteomic investigation of cell-derived ECM isolated from glomerular cells in culture identified 35 highly connected matrix components and a number of these were differentially expressed in mono- versus coculture ECMs (12). Although a unique ECM niche, the GBM contains proteins that are found in other basement membranes; however, the specific arrangement of matrix isoforms in the GBM provides its distinctive composition and function.

Adhesion receptors such as integrins, syndecans, and dystroglycan connect cells to their associated ECM ligands in the extracellular space and to the cellular cytoskeleton inside the cell (Figure 2). The mature focal adhesion complexes that result from this cell-matrix interaction are vital in all aspects of normal cell development including growth, proliferation, signaling, differentiation, migration, and survival $(13,14)$. Furthermore, in addition to maintaining GBM structure, secreted growth factors support the ECM through organized cell-cell signaling (13).

The study of ECM components that maintain the integrity of the GBM has advanced the understanding of what constitutes a healthy glomerulus. However, disruption to this specialized ECM niche can alter the function of the filtration barrier and cause the leakage of albumin into the urine (albuminuria). Of the nine major proteins discovered in the GBM, genetic mutations in type IV collagen and laminin are reported to cause glomerular disease in humans $(15,16)$. Although these distinct genetic mutations have been defined, the pathogenesis of the majority of kidney diseases such as diabetic nephropathy are less clear, and it is thought that environmental influences may have a role. Not all conditions that present with proteinuria and glomerular disease have a genetic component, which is one of the main limitations in the diagnosis and treatment of these rare diseases. Animal models have been beneficial in deciphering pathogenic pathways of disease; however, targeted treatments for genetic diseases of the GBM currently do not exist. This review will cover key findings and recent discoveries of mechanisms that sustain a healthy GBM and known pathogenic pathways that lead to genetic kidney disease. In addition, recent advances and novel approaches in the field of ECM in glomerular health and disease will be discussed. 


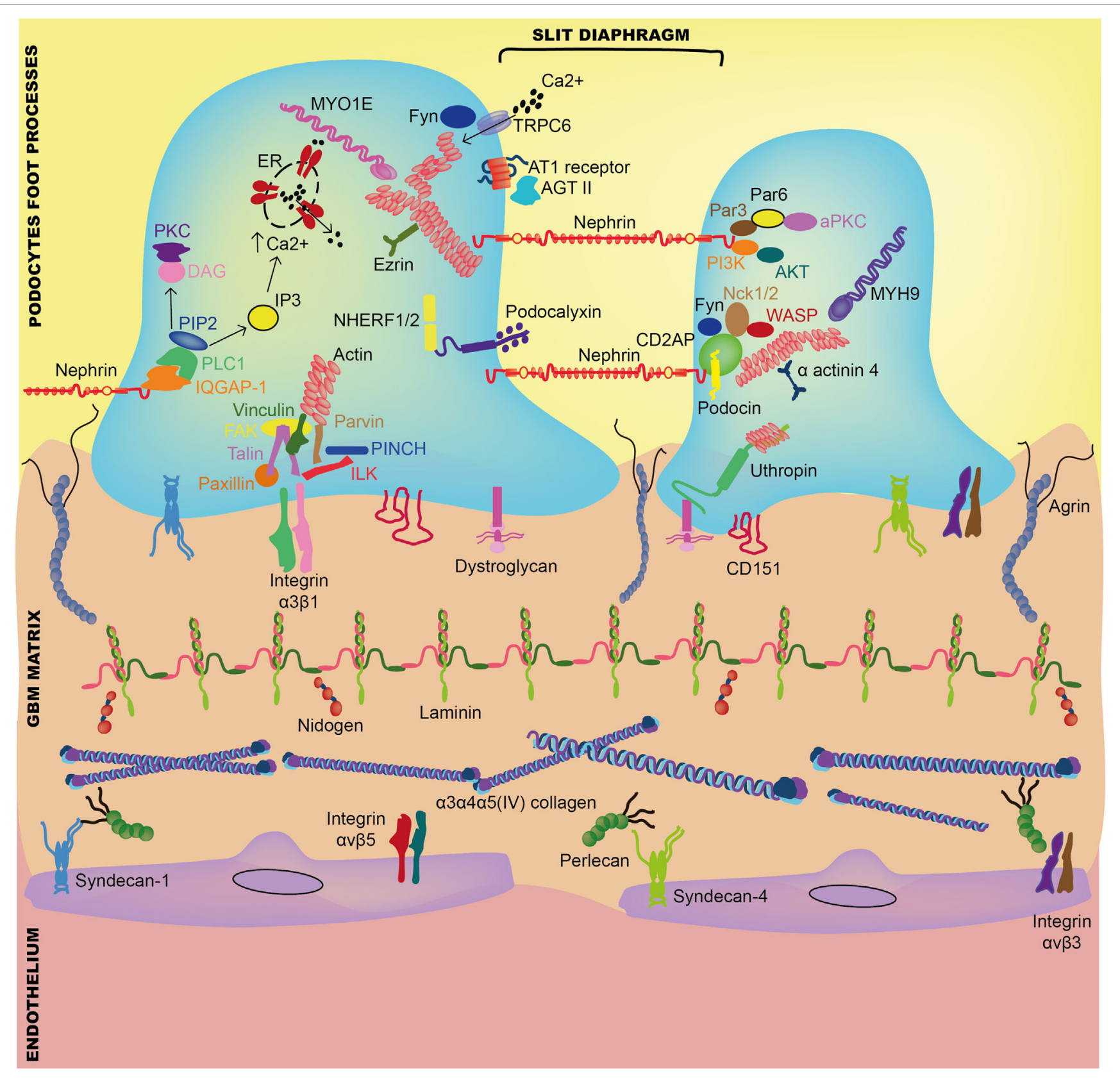

FIGURE 2 | Interaction between components of the glomerular basement membrane and adjacent glomerular cells. Abbreviations: AGT II, angiotensin-II; AKT, protein kinase B; aPKC, atypical protein kinase C; AT1, angiotensin-I; CD2AP, CD2-associated protein; DAG, diacylglycerol; ER, endoplasmic reticulum; FAK, focal adhesion kinase; IQGAP-1, IQ motif containing GTPase-activating protein-1; ILK, integrin-linked kinase; IP3, inositol triphosphate; MYH9, myosin heavy chain 9; MYO1E, myosin-1E; PIP3, phosphatidylinositol 4,5-biphosphate; Nck1, non-catalytic region of tyrosine kinase adaptor protein-1; $\mathrm{NHERF} / 2, \mathrm{Na}^{+} / \mathrm{H}^{+}$exchanger regulatory factor-1/2; PI3K, phosphoinositide 3-kinase; PINCH, Cys-His-rich protein; PKC, protein kinase C; PLC, phosphatidylinositol phospholipase C; TRPC6, transient receptor potential cation channel-6; WASP, Wiskott-Aldrich syndrome protein.

\section{GBM BIOLOGY IN HEALTH AND DISEASE}

\section{Type IV Collagen}

In common with other basement membranes, type IV collagen forms a major structural component of the GBM and contributes significantly to its stability and assembly $(17,18)$. There are six collagen IV $\alpha$-chains, $\alpha$ (IV) to $\alpha 6($ IV), encoded by the genes
COLA4A1 and COL4A2 on chromosome 13; COL4A3 and COL4A4 on chromosome 2, and COL4A5 and COL4A6 on the $\mathrm{X}$ chromosome. Each collagen IV $\alpha$-chain is composed of an $\mathrm{N}$-terminal $7 \mathrm{~S}$ domain, Gly-X-Y repeats and a non-collagenous (NC1) domain at the C-terminus (Figure 3). It is the unique interrupted Gly-X-Y amino acid triplet repeats within these three domains that give collagen IV its flexible quality, enabling 


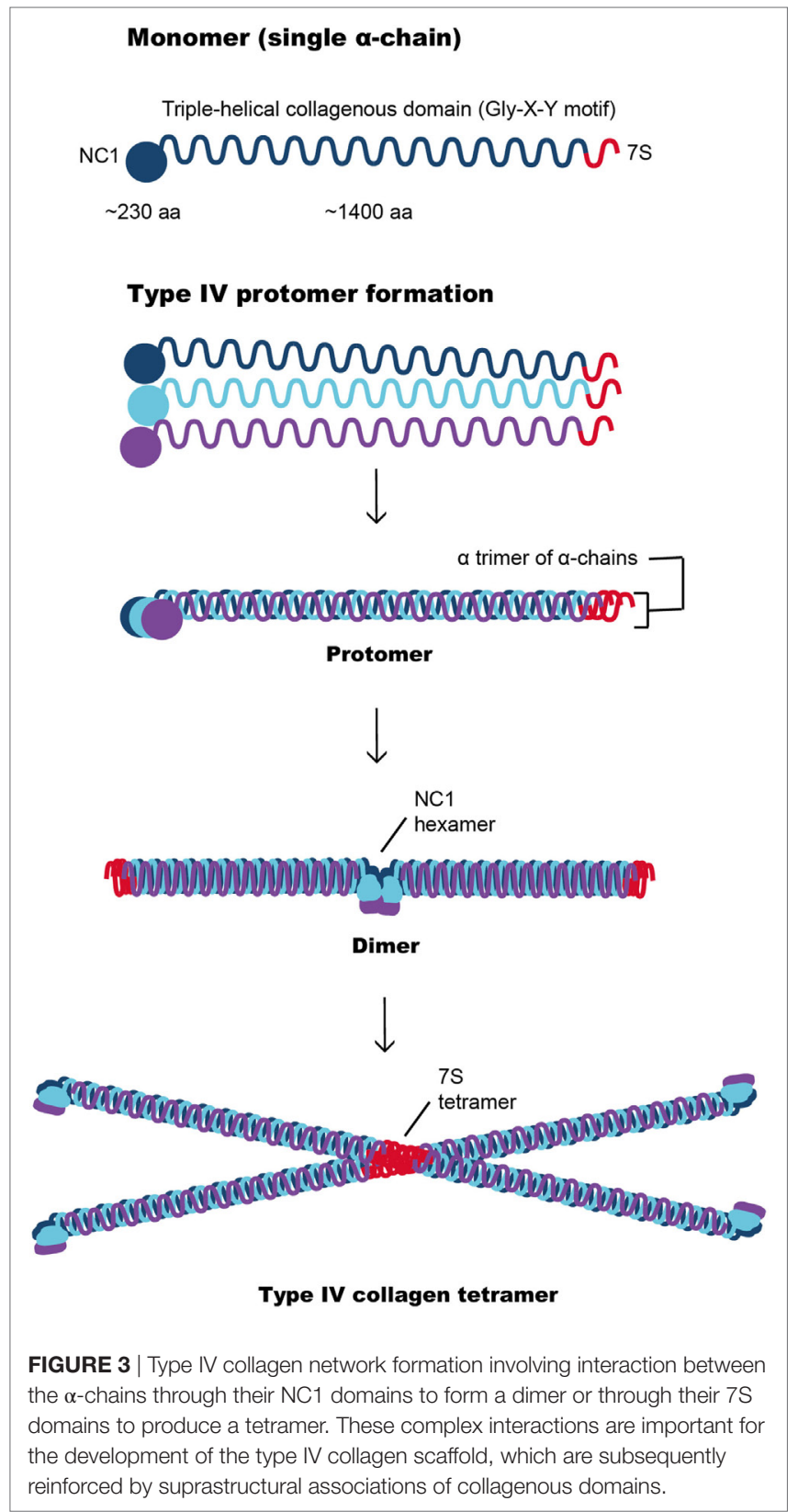

it to successfully form basement membranes (19). The $\alpha$-chains assemble in the endoplasmic reticulum forming the collagen IV triple helix or protomers, which are released into the extracellular space where they undergo polymerization via head-to-head $\mathrm{NH} 2$ - and $\mathrm{COOH}$-terminal domains that result in unique collagen IV hexameric networks (20).

The six collagen IV $\alpha$-chains form three distinct networks comprising helical heterotrimers these are $\alpha 1 \alpha 1 \alpha 2$ (IV), $\alpha 3 \alpha 4 \alpha 5$ (IV), and $\alpha 5 \alpha 5 \alpha 6(\mathrm{IV})$, and they are present in different glomerular compartments $(20,21)$. During glomerulogenesis, there is a shift in the composition of collagen IV $\alpha$-chains involving a transition from $\alpha 1 \alpha 1 \alpha 2$ (IV), predominantly found in the immature S-shaped and early capillary loop GBM, to the $\alpha 3 \alpha 4 \alpha 5$ (IV) network, which defines the mature GBM (22). The $\alpha 3 \alpha 4 \alpha 5$ (IV) isoform is primarily produced by podocytes, whereas the $\alpha 1 \alpha 1 \alpha 2$ (IV) is present in all cell types including endothelial cells, podocytes, and mesangial cells (5). Type IV collagen networks differ between species and their expression is not solely restricted to the GBM, but these protomers have also been found in the mesangial matrix and Bowman's capsule $(23,24)$. Mechanisms underlying the transition between collagen IV isoforms during glomerular development are not fully understood. However, it is considered that the $\alpha 3 \alpha 4 \alpha 5$ (IV) is less susceptible to proteolytic degradation than the $\alpha 1 \alpha 1 \alpha 2$ (IV) isoform, which suggests that it may have a crucial role in maintaining the structural integrity of the GBM (25). The lateral links between the $\alpha 3 \alpha 4 \alpha 5$ (IV) chains are also essential in fortifying networks within the GBM (26). The $\alpha 1 \alpha 1 \alpha 2$ (IV) and $\alpha 3 \alpha 4 \alpha 5$ (IV) networks are both present in the glomerular capillary tuft, whereas the $\alpha 5 \alpha 5 \alpha 6$ (IV) is localized to the basement membrane of Bowman's capsule. Overall, the role of type IV collagen networks in supporting the GBM are crucial, and the absence or reduction of the $\alpha 3 \alpha 4 \alpha 5$ (IV) chains reduces the quantity of protomers secreted, leading to thin basement membranes and Alport syndrome (AS) $(27,28)$.

\section{Alport Syndrome Clinical Features}

A diagnosis of AS should be suspected in individuals who present with glomerular hematuria and a family history of AS or renal failure without other identified causes and these individuals should undergo further investigations (29). The diagnosis of Alport was previously confirmed by the presence of lamellated GBM or abnormal deposition of $\alpha 3 \alpha 4 \alpha 5$ (IV) and $\alpha 5$ (IV) collagen chains from the GBM and skin, respectively, the latter of which reported moderate sensitivity in $80 \%$ males and high specificity (30). More recently, genetic testing has been a preferred diagnostic method, as it is less invasive than skin or kidney biopsy and has a diagnostic specificity of 95\% (29). Sanger sequencing was the gold standard for the diagnosis of AS where other techniques were unsuccessful; however, next-generation sequencing to screen genes corresponding to $\alpha 3, \alpha 4$, and $\alpha 5$ chains of type IV collagen has now succeeded this method (31).

The clinical phenotype in AS also includes ocular abnormalities and sensorineural hearing loss. Hearing loss was more likely to occur in $60 \%$ of patients with missense mutations before 30 years of age, which is lower than the $90 \%$ risk in individuals with other mutations. In the majority of patients with AS, the auditory deficit affects the higher sound frequencies, and it usually progresses to hearing loss within conversational range. The ocular defects in X-linked and autosomal recessive AS include anterior lenticonus, perimacular retinal flecks, posterior corneal vesicles, and recurrent corneal erosions (32).

\section{Etiology and Pathogenesis}

The significant role of type IV collagen in the maintaining the GBM has been highlighted by mutations in the $\alpha 3, \alpha 4$, and $\alpha 5$ chains of type IV collagen encoded by COL $4 A 3, C O L 4 A 4$, and COL4A5 genes, respectively, which cause AS $(15,33)$. There are two main modes of inheritance in AS: X-linked and autosomal recessive $(30,34,35)$. The X-linked form of AS occurs in around 
$80 \%$ of patients and involves mutations in the COL4A5 gene encoding the $\alpha 5$ chain of type IV collagen. All affected males with the X-linked AS will ultimately develop end-stage renal disease (ESRD) requiring dialysis or kidney transplantation by at least 60 years of age (30). Female patients with X-linked AS also develop proteinuria; however, only around 30\% develop ESRD at 60 years (36). Approximately $15 \%$ of patients with AS have the autosomal recessive form of disease arising from mutations in COL4A3 or COL4A4, and the phenotype of these patients is similar to those with X-linked AS. A final small group of patients have heterozygous mutations in $C O L 4 A 3$ or COL4A4 and manifest with an AS phenotype.

Genetic abnormalities in the COL4A5 gene have a significant influence on the rate of progression to ESRD in males with X-linked AS $(30,37)$. Female carriers of XLAS syndrome are known to experience milder disease than affected males, and $\mathrm{X}$-chromosome inactivation may be a major determinant of the difference in phenotype $(36,38)$. All affected males and around $95 \%$ of females experience microscopic hematuria from early childhood and episodes of macroscopic hematuria may present episodically throughout life $(30,36)$. In a large cohort study of families with X-linked AS, the type of genetic mutation determined the risk of progression to ESRD and hearing loss (30). Male patients with large deletions, nonsense or small mutations carried a significant $90 \%$ probability of developing ESRD, whereas individuals with a missense or a splice mutation had a $50-70 \%$ risk of this complication.

In AS, there is a defect in the switch from the $\alpha 1 \alpha 1 \alpha 2$ (IV) to the $\alpha 3 \alpha 4 \alpha 5$ (IV) networks during glomerulogenesis and instead the $\alpha 1 \alpha 1 \alpha 2(\mathrm{IV})$ network predominates in the mature GBM $(25,39)$. Changes in type IV collagen networks may influence signaling via discoidin domain receptor 1 (DDR1) and integrin $\alpha 2 \beta 1(40,41)$, which may in turn alter podocyte function. These extracellular receptors, DDR1 and DDR2, belong to a family of receptor tyrosine kinases, which are important for cellular regulation (42). Receptor tyrosine kinases are typically activated by peptide-like growth factors; however, activation of DDRs is mediated by collagens, which act as DDR ligands (43-45). Mice deficient in $\alpha 2$ integrin do not have a renal phenotype; however, DDR1-knockout mice display thickening of the GBM, podocyte foot effacement, and proteinuria $(46,47)$. Mice with AS and DDR1 deficiency or haploinsufficiency had improved renal function and increased survival (48). These models suggest a potential role for DDR1 signaling in the pathogenesis of AS; however, exact mechanisms are not fully understood.

The structural components of the glomerulus including the capillary loops, mesangial cells, and matrix and podocytes may also undergo damage due to high-mechanical forces exerting biomechanical strain on glomerular cells. The effects of increased blood pressure were seen in Alport mice treated with L-NAME, which is an inhibitor of nitric oxide synthase and causes hypertension. These mice developed proteinuria and severe ultrastructural defects in the GBM (49). In contrast, the angiotensin-converting enzyme (ACE) inhibitor ramipril delayed the progression to proteinuria in the COL4A3 knockout mice and has been shown to improve survival in both mouse models and human disease $(50,51)$. Recent work highlighted that biomechanical strain-sensitive activation of mesangial cell actin dynamics may be important in the pathogenesis of AS. This was demonstrated by the upregulation of endothelin A receptor expression in the glomeruli of Alport mouse models, which lead the formation of mesangial filopodia and the deposition laminin $\alpha 2(52,53)$ in the GBM. The accumulation of mesangial proteins within the GBM led to the activation of focal adhesion kinase in podocytes and nuclear translocation of NF- $\kappa \mathrm{B}$, which induces a pro-inflammatory state and the release of cytokines, chemokines, and metalloproteinases (54). Interestingly, matrix metalloproteinases not only show increased expression in the glomeruli of Alport mouse models but pharmacological inhibition of these inflammatory mediators before the onset of proteinuria prevented disease progression and improved survival $(55,56)$. The inhibition of transforming growth factor- $\beta 1$ was thought to slow disease progression and although this inhibitor prevented GBM thickening, it did not prevent foot process effacement $(57,58)$. Advances in GBM biology have enabled better understanding of pathogenic mechanisms in AS; however, more research is required to enable the development of therapeutic targets that may delay or stop the progression of the disease.

\section{Treatments}

Medical treatment using ACE inhibition has demonstrated significant benefits including the reduction of proteinuria and delay of ESRD in AS $(51,59)$; however, mechanisms of action of these drugs are not fully understood. In a retrospective study, the use of ACE inhibitors appeared to delay renal failure and improve life expectancy in three generations of Alport families (51). Findings resulting from the EARLY PRO-TECT Alport trial of the effects of RAS blockade on the progression of ESRD will be important in supporting the development of emerging candidate therapies $(60,61)$. At the point of requiring renal replacement therapy, renal transplantation is associated with good long-term outcomes (62). Appropriate donor selection is crucial as the risk of penetrance of COL4A5 gene mutation is particular high within families, although transplantation among relatives has been reported $(63,64)$. This method is by no means suboptimal and important points need to be considered, which include the acceptance of donors without proteinuria and the counseling of families who may experience an increased risk of ESRD in the recipient (64).

A small proportion of around 3\% of patients with AS suffer from severe post-transplant anti-GBM disease (63). This complication typically presents with hematuria, which progresses to graft rejection. The prognosis for survival in these patients who undergo subsequent transplantation is poor (65). The risk of posttransplant anti-GBM nephritis in patients with AS is increased if the underlying defect is due to a gene deletion (66). Antibodies in anti-GBM are generated against the $\alpha 5$ (IV) and $\alpha 3$ (IV) chains in patients with $\mathrm{X}$-linked and autosomal recessive AS, respectively (67). Affected individuals display histological similarities to Goodpasture disease; however, post-transplant anti-GBM disease is different in that it does not occur spontaneously and it involves an alloimmune response against normal type IV collagen in the form of foreign antigenic epitopes.

Future alternative options to conventional therapy include gene replacement and several approaches have been employed, 
which may have broader implications for the development of therapeutic targets that aim to repair the GBM after pathological insult. The insertion of a full-length $C O L 4 A 3$ under control of a tetracycline inducible promoter into Col4a $3^{-/-}$mice significantly reduced proteinuria, increased survival, and restored missing collagen IV networks despite the persistence of ultrastructural damage within the GBM (68). Advances in stem cell technology have also explored the possibility of restoring type IV collagen network to the GBM in Alport AS. Replacement through the transplantation of wild-type bone marrow-derived stem cells into irradiated $\mathrm{Col}_{4} \mathrm{a3}^{-/-}$mice resulted in possible recruitment of podocytes and mesangial cells within damaged glomeruli and a partial re-expression of $\alpha 3$ (IV) collagen chains (69). Histologically, these mice had improved glomerular architecture associated with a significant proteinuria compared with untreated $\mathrm{Col}_{4} \mathrm{a3}^{-/-}$mice or irradiated $\mathrm{Col}_{4} \mathrm{a3}^{-/-}$mice that had received bone marrow from adult $\mathrm{Col}_{4} \mathrm{a}^{-/-}$mice. Stem cell therapies have highlighted novel approaches for the treatment of AS; however, these methods require further refinement before their application in human disease.

\section{Heterozygous Mutations in COL4A3 and COL4A4 Clinical Features}

Individuals with a single mutation in COL $4 A 3$ or COL $4 A 4$ present with microscopic hematuria in childhood and this is due to the diffuse thinning of the GBM. Patients with thin GBMs may have episodic macroscopic hematuria throughout life and are at risk of developing proteinuria and progressive CKD. Approximately $1 \%$ of the population is affected by thin GBMs and at least twothirds have another affected relative (70). These patients do not usually suffer from extrarenal manifestations such as hypertension or deteriorating renal function requiring dialysis or kidney transplantation.

\section{Etiology and Pathogenesis}

Heterozygous mutations in the COL4A3 and COL4A4 gene account for up to $40 \%$ of cases in families with thin GBMs and these mutations demonstrate linkage to the COL $4 A 3 / C O L 4 A 4$ locus, which is also affected in autosomal recessive AS $(71,72)$. The majority of these patients have non-progressive hematuria; however, a number of individuals will experience a deterioration in renal function with pathological changes, which include GBM thickening, proteinuria, nephrotic syndrome, and progressive CKD. Of the 82 patients from a cohort of patients with thin GBMs who had heterozygous mutations in COL4A3 and COL4A4, around $37.8 \%$ developed CKD and $19.5 \%$ progressed to ESRD (73).

Patients with thin GBMs rarely require treatment, however, given the variation in presentation in a minority of individuals, long-term monitoring including blood pressure, proteinuria, and renal function is strongly recommended.

\section{HANAC Syndrome}

\section{Clinical Features}

Hereditary angiopathy, nephropathy, aneurysm, and cramps comprise HANAC syndrome. The disease phenotype in families is characterized by muscle cramps, mild cerebral small-vessel disease, retinal artery tortuosity, intracranial aneurysms, and renal disease associated with multicystic kidneys, occasional hematuria, and decreased glomerular filtration rate in older patients (74-76). Intrarenal structural abnormalities occur within Bowman's capsule, tubular basement membrane (TBM), and peritubular capillaries; however, the integrity of the GBM appears normal.

\section{Etiology and Pathogenesis}

Mutations in COL4A1 affecting the $\alpha 1 \alpha 1 \alpha 2$ (IV) network were first identified in families with porencephaly, a condition characterized by cystic and cerebral white matter lesions (77). Smallvessel disease affecting the brain and eye has also been described in a single family with COL4A1 mutation (78). Missense mutations in the COL4A1 gene, localized in exons 24 and 25, which affect glycine residues and interrupt the Gly-Xaa-Yaa amino acid repeat have been described in three families with autosomal dominant inheritance of the disease (79). In mice with the Col4a1 G498V mutation used to model HANAC syndrome, there was evidence of delayed glomerulogenesis and podocyte differentiation without a reduction in nephron number (80). Given the extensive expression of the $\alpha 1 \alpha 1 \alpha 2$ (IV) network as well as its importance in glomerular development and podocyte differentiation, it is not surprising that mutations in the COL4A1 gene may lead to a systemic phenotype. Treatment for this condition is largely supportive, and distinct therapeutic targets have not yet been defined.

\section{Laminin}

Laminins are large glycoproteins that produce $\alpha, \beta$, and $\gamma$ heterotrimers, which provide a structure for the attachment of matrix proteins within the ECM (81). In humans, there are at least 15 distinct laminin heterotrimers composed of an assembly of 4 $\alpha$-, $4 \beta$-, and $3 \gamma$-chains (Figure 4) $(82,83)$. Laminin heterotrimers have tissue-specific expression depending on their $\alpha \beta \gamma$ composition. The predominant laminin heterotrimer secreted by endothelial cells and podocytes is $\alpha 5 \beta 2 \gamma 1$ or LM-521, which features in the mature GBM and replaces $\alpha 1 \beta 1 \gamma 1$ (LM-111) and $\alpha 5 \beta 1 \gamma 1$ (LM-511), which are present during glomerulogenesis $(3,84,85)$. The majority of laminins form cross-shaped structures composed of one "long arm" formed by $\alpha \beta \gamma$ chains via coiled-coil interactions and disulfide bonding, and three "short arms" with $\mathrm{NH}_{2}$-terminal globular (LN) domains $(86,87)$. These LN domains in the short arms of cross-shaped structures mediate trimer polymerization, which has a significant role in basement membrane formation (88). Another unique feature of laminin is the $\alpha$-chains that have $\mathrm{C}$-terminal laminin globular (LG) domains at the distal end of the long arm, which binds the laminin trimer to laminin receptors (89).

The LG domain mediates interactions with cell surface receptors including integrins and dystroglycan $(90,91)$. Integrin $\alpha 3 \beta 1$ binds to LM-511 and LM-521 through the LG domain of the $\alpha 5$ chain (26). This integrin is a key surface receptor responsible for capillary loop formation and mesangial cell organization, and podocyte-specific deletion affects normal glomerular development $(92,93)$. Changes in expression of the $\alpha$-dystroglycan subunit that binds to laminin occurs in glomerular disease; however, deletion in podocytes did not affect susceptibility to 


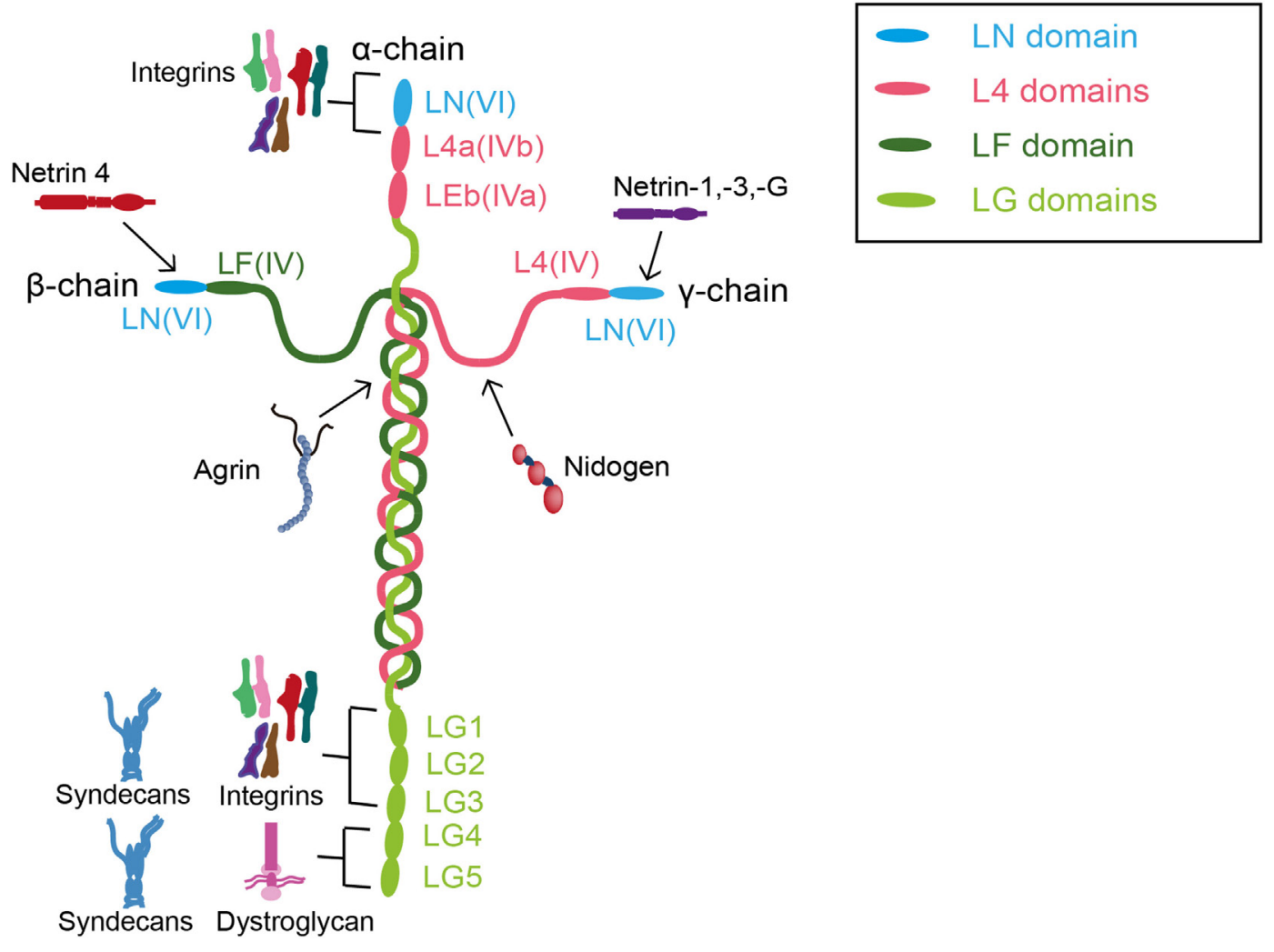

FIGURE 4 | Interactions between laminin and other extracellular matrix components in the glomerular basement membrane. Abbreviations: LF, globular $F$ terminal domain; LG, globular C terminal domain; LN, globular $\mathrm{N}$ terminal domain.

injury or recovery from damage in the kidneys (94-98). In addition, glycosylation of $\alpha$-dystroglycan which disrupts its binding with laminin resulted in mild podocyte foot process effacement without proteinuria (99).

\section{Pierson Syndrome \\ Clinical Features}

Pierson syndrome is a rare condition inherited in an autosomal recessive manner with phenotypic variability and characterized by congenital nephrotic syndrome which progresses to ESRD within the first year of life. In some cases, renal manifestations may present as early as the prenatal period with oligohydramios and kidney enlargement, which can be detected using ultrasonography $(100,101)$. Children with Pierson syndrome are affected by renal impairment soon after birth; however, with renal replacement therapy, some have lived for up to 2 years of age (102). There are currently no reports to date of adult patients with Pierson syndrome. Extrarenal manifestations include fixed pupil constriction (microcoria) but not all patients with Pierson syndrome have eye abnormalities $(103,104)$. Congenital muscle hypotonia and neurodevelopmental abnormalities may also present in some cases (105).

\section{Etiology and Pathogenesis}

Pierson syndrome is caused by the homozygous or compound heterozygous mutations in $\beta 2$-laminin encoded by the $L A M B 2$ gene
(106). Given the variable expression resulting from mutations in the $L A M B 2$ gene, there appears to be a broad spectrum of phenotypic presentations and screening of this gene is to be considered should there be no mutations found in NPHS1, NPHS2, or WT1 (104). Patients with milder missense LAMB2 mutations, including R246Q and C321R, present with a less severe renal and extrarenal phenotypes $(16,104)$. In Pierson syndrome, there appears to be a deficiency of the major laminin protomer LM-521 containing $\beta 2$-laminin expression, which predominates in mature GBM. Mice with a null mutation in $L A M B 2$ which display the clinical features seen in Pierson syndrome are a good model for the study of this condition (107). The loss of LM-521 in the normal mature GBM is replaced by LM-511, which usually features in the developmental GBM. The generation of $L A M B 2^{-/-}$mice has been useful in that they recapitulate Pierson syndrome, and develop congenital albuminuria, podocyte foot process effacement, and are non-viable from 3 weeks of age due to neuromuscular defects and nephrotic syndrome $(107,108)$. In the $L A M B 2^{-/-}$mice, there was an ectopic deposition of several laminins, a possible a compensation for the loss of LM-521, and mislocalization of anionic sites despite a structurally normal GBM (109). Like in the human disease, proteinuria preceded structural abnormalities in the podocyte and slit diaphragm in these mice, which suggests the premature onset of pathological mechanisms before the onset of damage within the GBM.

Using the Lamb2 $2^{-/-}$mice in the study of Pierson syndrome has its limitations in that they die at a young age, and therefore 
the long-term effects on the kidneys and neuromuscular junction are not known. Transgenic mice with varying podocyte expression levels of R246Q-mutant rat $\beta 2$-laminin were subsequently developed to investigate the degree to which missense mutations in the $L A M B 2$ gene cause proteinuria. These mice were generated by crossing $L A M B 2^{-/-}$mice with transgenic mouse lines expressing rat laminin- $\beta 2$ either in muscle or podocytes (110). In transgenic mice where laminin- $\beta 2$ was restricted to the kidney, the degree of proteinuria was milder compared with non-transgenic Lamb2 $2^{-/}$mice, but severe kidney and neuromuscular defects were maintained. Where laminin- $\beta 2$ was limited to muscle expression, synaptic function was restored; however, mice died from kidney disease at 1 month of age. Transgenic podocyte-specific Lam $\beta 1$ expression in Lamb2 $2^{-/-}$mice successfully increased LM-511 trimer deposition, eliminated nephrotic syndrome, and extended survival, highlighting a potential new therapeutic approach (111). These findings implicate potential targets for future therapies and that targeting the kidneys alone may not be effective in Pierson syndrome. Treatment for Pierson syndrome is currently supportive.

\section{Nidogen}

Also known as entactins, nidogen-1 and nidogen-2 are dumbbellshaped basement membrane proteins with three globular domains connected by two threads separating G-domains (112). Different genes encode nidogen- 1 and nidogen-2, and nidogen- 1 binds to the short arm of the laminin $\gamma 1$ chain and type IV collagen, which is thought to bridge these separate networks in the basement membranes $(113,114)$. It is uncertain if nidogen may have an important role in basement membrane formation, as the deletion of either of the nidogen genes produce viable mice with a normal phenotype $(115,116)$. Interestingly, nidogen-2 knockout mice are more susceptible to the induction of renal injury compared with the wild-type mice, and these mice develop increased blood pressure, serum creatinine, and albumin excretion (117). Nidogen-2 may have a protective or reparative role in the GBM; however, mechanisms are not known. In mice with simultaneous deletion of both nidogen-1 and nidogen-2, basement membrane formation occurs normally; however, these mice die perinatally and develop subsequent basement membrane abnormalities in the lungs and heart (10). Despite a normal GBM appearance in double nidogen knockout mice, there was phenotypic variability and a subgroup developed renal dysgenesis or agenesis (unilateral or bilateral), hydronephrosis, and polycystic defects. To date, the effect of mutations in nidogen genes in the human kidney is not known; however, quantitative mass spectrometry proteomics have identified that the NID1 gene, which encodes for nidogen-1, promotes lung metastases of breast cancer and melanoma (118).

\section{Heparan Sulfate Proteoglycans}

The three major HSPGs identified in basement membranes include perlecan, collagen XVIII, and agrin. The commonest HSPGs in basement membranes during development are perlecan and collagen XVIII, whereas agrin predominates in the mature $\operatorname{GBM}(8,119,120)$. Perlecan binds to nidogen, laminin, and collagen IV through heparan sulfate chains in the immature
GBM and after glomerulogenesis, a higher concentration of perlecan is found in the mesangial matrix (121-123). Perlecan mutant mice have normal kidneys; however, they appear to be more susceptible to proteinuria after albumin overload. Mice deficient in collagen XVIII have deranged creatinine levels and display mesangial matrix expansion, but did not display GBM abnormalities (124-126). Recent ultra-high resolution STORM imaging correlated with electron microscopy reveals differences in the distribution of agrin in mouse and human GBM (127). In mice, the C-terminal end of agrin is located adjacent to cell membranes and the $\mathrm{N}$-terminus is found toward the center of the GBM, whereas in humans, agrin is mainly present in the subepithelial area where podocytes reside. Therefore, the phenotype seen in mouse models may not represent directly relevance to human mutations due to interspecies differences in the GBM distribution of HSPGs.

The heparan- and chondroitin-sulfate glycosaminoglycan side chains frequently undergo sulfation, resulting in a negatively charged proteoglycan, which is thought to contribute to charge selectivity within anionic sites in the $\operatorname{GBM}(9,128)$. The anionic sites within the GBM can be detected with polyethyleneimine and cationised ferritin. Agrin has an N-terminal domain bound to the long arm of LM-521 and a C-terminus bound to integrins and dystroglycan, which implicates a potential role in charge selectivity (129). Mice with a podocyte-specific mutation of agrin had fewer negatively charged sites and a shorter length of protein; however, these defects did not result in proteinuria or GBM abnormalities after an albumin overload (9). The deletion of both perlecan and agrin in mice had no effect on permselectivity of the filtration barrier (130). Whether charge selectivity exists within the glomerular filtration barrier is not clear, and these studies confirm that HSPGs may not have a major role in this function.

\section{HSPGs in Glomerular Disease}

Mutations in HSPGs in human glomerular disease are not well defined and remain limited to immunohistochemical staining in single case reports. Global or segmental loss of staining for heparan sulfate chains in the GBM is evident in lupus nephritis, membranous nephropathy, minimal change disease, and diabetic nephropathy but not in IgA nephropathy or AS (131). The loss of HSPG in the GBM is also observed in individual case reports of C3 glomerulopathy and Denys-Drash syndrome $(132,133)$. Similarly, animal models including the mouse model of lupus nephritis (MRL/lpr), rat model of active Heymann nephritis, or membranous nephropathy and rat model of streptozotocininduced diabetic nephropathy show reduced GBM heparan sulfate staining (134-136). A potential mechanism accounting for the reduction of heparan sulfate may be the increase in active heparanase in kidney disease, which shortens these chains through hydrolyzation of glycosidic bonds at specific sites (137). In mouse models of passive Heymann and anti-GBM nephritis, the increase in glomerular heparanase is accompanied by the loss of heparan sulfate, proteinuria, and complement activation. Treatment of these mice with anti-heparanase antibodies reverses proteinuria (138). Decreased expression of heparan sulfate may be due to these domains being masked by the deposition of autoantibodies and immune complexes in the GBM, which is seen 
in MRL/lpr mice and patients with systemic lupus erythematosus (SLE) (139). The reduction in heparan sulfate has been recently linked to complement activation. There appears to be a loss of complement regulator factor $\mathrm{H}$ in lupus nephritis and anti-GBM disease, which leads to inadequate complement activation and glomerular injury $(140,141)$. There is clearly a role for HSPGs in the regulation of the GBM and characterization of physiological networks is required to understand its function in health and disease.

\section{Fibronectin}

Fibronectin is a large $270-\mathrm{kDa}$ glycoprotein with diverse function, which binds to heterodimeric cell surface receptors such as integrins and other ECM components (142). There are three modular domains of fibronectin, which includes type I and II repeats maintained by disulfide bonds and type III repeats characterized by the absence of these bonds that enable it to undergo conformational changes (143-145). Fibronectin can occur in two forms. Plasma fibronectin is secreted into blood from hepatocytes in its soluble form and may integrate into the fibrillar matrix, a role previously attributed to cellular fibronectin (146, 147). Integrins are important in linking fibronectin to the actin cytoskeleton and enabling the process of matrix assembly; however, fibrin organization within fibrils is not known (148). Mechanical forces regulate interactions between fibronectin and collagen; however, these findings have been limited to in vitro fibroblasts, and the role of this novel mechanism in vivo is not known (149). Fibronectin is not an abundant component of the GBM; indeed, our proteomic analyses demonstrated a fivefold higher abundance of type IV collagen compared with fibronectin in healthy glomerular ECM (11). In disease, however, there appears to be a greater glomerular deposition of fibronectin, and this has been observed in a diabetic nephropathy model (150).

\section{Fibronectin in Glomerular Disease}

Fibronectin glomerulopathy is inherited in an autosomal dominant manner and is characterized by proteinuria, microscopic hematuria, hypertension, and abnormal renal function. Glomerular deposition of fibronectin can lead to progressive ESRD between the second and sixth decade of life (151). Light microscopy findings include enlarged glomeruli with minimal hypercellularity, and mesangial and subendothelial space deposits. Granular, fibrillary, or mixed deposits within the glomeruli can also be detected by electron microscopy. A significant finding in fibronectin glomerulopathy is the strong positive staining of fibronectin observed in the glomeruli. The immunoreactivity for immunoglobulins, complement proteins, laminin, and type IV collagen was absent or weak. Fibronectin deposition may potentially occur in other glomerular diseases, evident in mouse models of SLE and patients with lupus nephritis (152). However, recent proteomic analyses of laser-captured microdissected glomeruli comparing living-related healthy donors and patients with glomerular disease confirm that fibronectin specifically expressed in patients with fibronectin glomerulopathy (153). Mutations causing fibronectin glomerulopathy are not well studied; however, in a large Italian pedigree, linkage at the FN1 locus at $2 \mathrm{q} 32$ was detected and dominant mutations in this gene contributed to $40 \%$ of cases in this group (154).

\section{Transcription Factors}

There are several transcription factors that have a role in regulating the GBM and ECM proteins. The LIM-homeodomain transcription factor encoded by the $L M X 1 B$ gene is highly expressed in podocytes, with LIM domains at the $\mathrm{N}$-terminus facilitating protein interactions and a central homeodomain enabling DNA binding. Mutations in the $L M X 1 B$ gene result in the absence or inactivation of this central homeodomain, which is associated with nail patella syndrome (NPS) (155). In the LMX1B conditional knockout mouse, there is a decreased expression of COL4A3 and COL4A4 genes in the glomeruli (156). In addition, $L M X 1 B$-deficient podocytes displayed structural abnormalities including a reduced number of foot processes that were dysplastic and lacked slit diaphragms. The levels of CD2-associated protein and podocin expression were also reduced in $L M X 1 B$-deficient podocytes, which implicated a potential role for $L M X 1 B$ in regulating these key proteins.

\section{Nail Patella Syndrome}

Nail patella syndrome, also known as hereditary osteoonychodysplasia, is a rare autosomal dominant disorder presenting with pleiotropic developmental abnormalities of dorsal limb structures involving hypoplasia or absence of the patellae, dystrophic nails, and dysplasia of the elbows and dorsal ilium (157). Phenotypic variability is present despite increased penetrance, and it appears that less than half of affected individuals with NPS develop nephropathy with proteinuria and hematuria $(158,159)$. Although the majority of patients experience a benign nephropathy, around $30 \%$ develop the risk of progression to renal failure.

Patients with NPS have over 140 heterozygous mutations in $L M X 1 B$ with missense, splicing, insertion, deletion, and nonsense alterations (155). LMX1B mutations that occur in the LIMhomeodomain are associated with skeletal defects in NPS (160). Mutations affecting the central homeodomain are significantly associated with renal involvement and this pattern appears to cluster in families (161). The microscopic findings of structural renal abnormalities in NPS are fairly non-specific and they include irregular GBM thickening with a "moth-eaten" appearance (162). To date, mechanisms leading to human glomerular disease in NPS have not been characterized and no distinct therapeutic targets have been identified.

\section{GBM Disease Involving Mutations in Podocyte Cytoskeletal Genes}

Myosins contribute to the cytoskeletal machinery of cells, hydrolyzing ATP, and interacting with actin to enable movement along muscle fibers. Non-muscle myosin heavy chain IIA (NMMHCIIA) is encoded by MYH9 and is expressed in glomerular podocytes, mesangial cells, and arteriolar and peritubullar capillaries. Mutations in the MYH9 gene can result in variable phenotypic presentations, which include Epstein and Fechtner syndromes, May-Hegglin anomaly, and Sebastian syndrome. Both Epstein and Fechtner syndromes were once considered to be variants of 
AS due to similarities in clinical phenotype, which include hereditary nephritis, hearing loss, and ocular abnormalities; however, type IV collagen expression appears to be preserved $(163,164)$. Patients with Epstein and Fechtner syndromes may also develop thrombocytopenia, macrothrombocytopenia, and leukocyte inclusions (165).

Genotype-phenotype correlations have suggested that mutations in the amino-terminal domain, which binds myosin light chains interacts with actin and utilizes ATP, may cause more severe phenotypic manifestations including nephritis, thrombocytopenia, and deafness before 40 years of age compared with mutations in the carboxy-terminal tail (166). The effects of MYH9 mutations on the GBM are not known, and microscopic findings have been fairly non-specific and likened to those observed in AS, with focal GBM thinning and foot process effacement (167). The expression of NMMHC-IIA in podocytes is reduced in MYH9-related disease $(167,168)$, but it is unclear whether these alterations affect GBM synthesis and organization. Our current knowledge on the long-term consequences of MYH9 mutations on the GBM remains limited, and $M Y H 9$ does not appear to be the only contributing factor to the spectra of conditions affecting the podocyte cytoskeleton.

\section{GBM Disease Caused by Abnormal Regulation of Adhesion Receptors}

The GBM is composed of condensed sheets of ECM with a supramolecular assembly built around two major networks of laminin and collagen IV (169). The role of the GBM is to support its ECM components and provide a scaffold for adjacent endothelial cells and podocytes. Cell-matrix interactions are key to the integrity of the filtration barrier maintained by cells adhering to the ECM through adhesion receptors, which include integrins, syndecans, and dystroglycan (13).

Integrins are $\alpha \beta$-heterodimeric cell surface receptors that engage with the ECM to mediate cell-matrix signaling, and the $\alpha 3 \beta 1$ heterodimer is particularly important in linking the podocyte and GBM (170). The importance of the $\alpha 3 \beta 1$ heterodimer is evident in mice lacking the integrin $\alpha 3$ subunit, which are nonviable within the first day of life due to developmental defects in the kidneys and lungs, accompanied by the loss of specialized morphology and thickened irregular GBMs (93). The podocytespecific deletion of $\alpha 3$ subunit results in an abnormal renal phenotype manifesting as nephrotic syndrome and subsequent renal failure (171). Individuals homozygous for mutations in the integrin $\alpha 3$ gene, ITGA3, have disrupted basement membrane structures and compromised barrier functions. These patients develop congenital nephrotic syndrome, interstitial lung disease, and epidermolysis bullosa (172). Mice with the homozygous deletion of integrin $\beta 1$ are not viable beyond the embryonic phase (173) and podocyte-specific deletion of the $\beta 1$ subunit in mice causes early renal failure at 3 weeks of age, progressive podocyte apoptosis and capillary loop and mesangium degeneration (174). Mutations of the integrin $\beta 1$ subunit in humans have not yet been described.

There is also a significant association between the tetraspanin CD151 and integrins in particular $\alpha 3 \beta 1$, which may have a role in cell migration (175). The global and podocyte-specific deletion of CD151 gene in mice results in proteinuria accompanied by the focal glomerulosclerosis, disorganization of the GBM, and tubular cystic dilation (171). Interestingly, the phenotype of CD151 knockouts significantly depends on the background of mouse used. CD151-deficient mice bred on an FVB background develop spontaneous and severe glomerular disease; however, this phenotype was not recapitulated in $\mathrm{C} 57 \mathrm{BL} / 6$ knockout models (176). The CD151 knockouts bred on a C57BL/6 background only display significant proteinuria when challenged with induced hypertension. Patients with a frameshift mutation in CD151 develop a similar phenotype to mice, which includes focal thickening and irregularity of the GBM as well as combined hearing loss and skin defects (177).

\section{Genetic Disorders of the TBM}

The TBM lies beneath the tubular epithelial cells and is in continuity with the interstitial connective tissue (178). Currently, there are no known genes exclusively linked to TBM abnormalities; however, these abnormalities are present in genetic disorders affecting the kidneys and often present alongside GBM or other extrarenal basement membrane phenotypes. The GBM is well preserved in HANAC syndrome, which is associated with mutations in the human COL4A1 gene; however, splitting and thickening of the TBM is observed (79). Defects in laminin $\alpha 5$, a major GBM and TBM protein component encoded by LAMA5 in mice manifest as GBM abnormalities, incomplete glomerular vascularization and polycystic kidneys, and defective interactions between tubular epithelial cells and the ECM may be the cause of cyst formations $(179,180)$. In AS, progressive disorganization of the GBM is followed by pro-fibrotic changes in the renal interstitium, which is characterized by abnormalities in the proximal renal tubular epithelium and defects in ECM turnover, leading to deterioration in renal function $(49,181,182)$. These few examples demonstrate that abnormalities in the TBM appear to occur alongside GBM defects; however, genetic and pathogenic mechanisms causing disease are yet to be fully understood.

\section{SUMMARY OF RESEARCH ADVANCES}

There have been significant research advances in glomerular disease since the early 1990s and the discovery of genetic disease associated with GBM defects and nephrotic syndrome. However, there remain unmet needs in the diagnosis, clinical care, and disease management. Importantly, there is currently a lack of targeted treatments across the spectrum of GBM conditions. Given the pivotal role of the GBM particularly in AS, a key area of focus is early diagnosis and treatment of disease, which has significant evidence in improving the long-term prognosis (51). The exponential discoveries through next-generation sequencing has enabled better understanding of the heterogeneity of GBM disease, which allows the integration of conventional therapies with a more stratified approach to treatment. Clinicians will therefore be able to avoid invasive biopsies and adjust tailor medications to a patient's needs more effectively. In addition, patients and families will have the opportunity to plan based on 
informed genetic counseling. The discovery of new therapeutics through the collaboration of the patients, clinicians, scientists, and industry is therefore necessary, to treat and even possibly prevent foot process effacement and GBM abnormalities (31). This in turn will generate a personalized diagnostic approach and potential therapeutic targets for the treatment of genetic kidney diseases affecting the basement membrane.

\section{PATIENT PERSPECTIVE}

Living with kidney disease presents challenges for families and around 4 in 10 patients have experienced a delay in or lack of diagnosis (183), which may result in inappropriate management. Diseases of the GBM are considered to be rare diseases, which affect the minority of people among other more prevalent conditions in the general population. To date, between 5,000 and 8,000 distinct rare diseases have been reported and in the UK, around 1 in 17 people (approximately 3.5 million) will develop a rare disease at some point in their lives (184). Of the rare diseases, around $75 \%$ of children are affected and at least $80 \%$ have had a genetic component identified. Although clinical teams can provide their expertise in treating families with rare diseases, it is important to recognize the personal challenges that patients' encounter, which include pathways to getting an appropriate diagnosis, implementation of care, and patient support networks. In addition, there are international efforts working toward the development of 200 new therapies for rare diseases by 2020 (35).

Research in to rare diseases is urgently required to enable better prognoses and targeted treatments for patients and their families. To support people with rare disease, patients' advisory groups play an important role in helping families through websites, leaflets, and personal contact. For genetic diseases of the GBM, an example organization is Alport UK, which is a patientled organization dedicated to empowering people who live with AS through the provision of support and information for this condition (185). Alport UK works with a multi-disciplinary internatonal collaboration consisting of researchers, clinicians,

\section{REFERENCES}

1. Russo LM, Bakris GL, Comper WD. Renal handling of albumin: a critical review of basic concepts and perspective. Am J Kidney Dis (2002) 39:899-919. doi:10.1053/ajkd.2002.32764

2. Miner JH. Glomerular basement membrane composition and the filtration barrier. Pediatr Nephrol (2011) 26:1413-7. doi:10.1007/s00467-011-1785-1

3. St John PL, Abrahamson DR. Glomerular endothelial cells and podocytes jointly synthesize laminin-1 and -11 chains. Kidney Int (2001) 60:1037-46. doi:10.1046/j.1523-1755.2001.0600031037.x

4. Abrahamson DR. Origin of the glomerular basement membrane visualized after in vivo labeling of laminin in newborn rat kidneys. J Cell Biol (1985) 100:1988-2000. doi:10.1083/jcb.100.6.1988

5. Abrahamson DR, Hudson BG, Stroganova L, Borza DB, St John PL. Cellular origins of type IV collagen networks in developing glomeruli. J Am Soc Nephrol (2009) 20:1471-9. doi:10.1681/ASN.2008101086

6. Abrahamson DR. Structure and development of the glomerular capillary wall and basement membrane. Am J Physiol (1987) 253:F783-94.

7. Harvey SJ, Zheng K, Sado Y, Naito I, Ninomiya Y, Jacobs RM, et al. Role of distinct type IV collagen networks in glomerular development and function. Kidney Int (1998) 54:1857-66. doi:10.1046/j.1523-1755.1998.00188.x academics, pharmaceutical companies, and other patient groups. This valuable partnership enables families and clinicians to access up-to-date and accurate resources, which aids clinical management toward a better quality of life and understanding of the AS. Another role of patient organizations is to assist with recruitment into national patient registries. These efforts are crucial to improving understanding about the natural history rare diseases, which may also inform the causative pathways and improved management for other more common disorders.

\section{SUMMARY/CONCLUSION}

Over the last two decades, important advances have been made in understanding the composition and function of the GBM, which is important for maintenance of filtration barrier integrity. Studies of core ECM components including laminin, collagen IV, HSPG, and nidogen in health and disease have highlighted the importance of these basement membrane proteins in enabling the GBM to function as the primary filtration barrier of the kidney. Significant progress in the application of global approaches including proteomics analyses has highlighted novel genotype-phenotype correlations, and thus enabling a broader range of molecular diagnoses for rare or unclassified glomerular diseases. In addition, these innovative approaches will enable the development of stratified therapeutic targets and guide the prognosis counseling of families with GBM diseases.

\section{AUTHOR CONTRIBUTIONS}

CC and RL research the topic and wrote the review. CC prepared the figures.

\section{FUNDING}

CC is a Clinical Research Training fellow funded by Arthritis Research UK (21370) and RL is supported by a Wellcome Trust Senior Fellowship award (202860/Z/16/Z).

8. Groffen AJ, Ruegg MA, Dijkman H, van de Velden TJ, Buskens CA, van den Born J, et al. Agrin is a major heparan sulfate proteoglycan in the human glomerular basement membrane. J Histochem Cytochem (1998) 46:19-27. doi:10.1177/002215549804600104

9. Harvey SJ, Jarad G, Cunningham J, Rops AL, van der Vlag J, Berden JH, et al. Disruption of glomerular basement membrane charge through podocyte-specific mutation of agrin does not alter glomerular permselectivity. Am J Pathol (2007) 171:139-52. doi:10.2353/ajpath.2007.061116

10. Bader BL, Smyth N, Nedbal S, Miosge N, Baranowsky A, Mokkapati S, et al. Compound genetic ablation of nidogen 1 and 2 causes basement membrane defects and perinatal lethality in mice. Mol Cell Biol (2005) 25:6846-56. doi:10.1128/MCB.25.15.6846-6856.2005

11. Lennon R, Byron A, Humphries JD, Randles MJ, Carisey A, Murphy S, et al. Global analysis reveals the complexity of the human glomerular extracellular matrix. J Am Soc Nephrol (2014) 25:939-51. doi:10.1681/ASN.2013030233

12. Byron A, Randles MJ, Humphries JD, Mironov A, Hamidi H, Harris S, et al. Glomerular cell cross-talk influences composition and assembly of extracellular matrix. J Am Soc Nephrol (2014) 25:953-66. doi:10.1681/ASN. 2013070795

13. Hynes RO. The extracellular matrix: not just pretty fibrils. Science (2009) 326:1216-9. doi:10.1126/science.1176009 
14. Hynes RO. Integrins: bidirectional, allosteric signaling machines. Cell (2002) 110:673-87. doi:10.1016/S0092-8674(02)00971-6

15. Kruegel J, Rubel D, Gross O. Alport syndrome - insights from basic and clinical research. Nat Rev Nephrol (2013) 9:170-8. doi:10.1038/nrneph.2012.259

16. Matejas V, Hinkes B, Alkandari F, Al-Gazali L, Annexstad E, Aytac MB, et al. Mutations in the human laminin beta2 (LAMB2) gene and the associated phenotypic spectrum. Hum Mutat (2010) 31:992-1002. doi:10.1002/ humu. 21304

17. Timpl R, Wiedemann H, van Delden V, Furthmayr H, Kuhn K. A network model for the organization of type IV collagen molecules in basement membranes. Eur J Biochem (1981) 120:203-11. doi:10.1111/j.1432-1033.1981. tb05690.x

18. Kuhn K, Wiedemann H, Timpl R, Risteli J, Dieringer H, Voss T, et al. Macromolecular structure of basement membrane collagens. FEBS Lett (1981) 125:123-8. doi:10.1016/0014-5793(81)81012-5

19. Hofmann H, Voss T, Kuhn K, Engel J. Localization of flexible sites in threadlike molecules from electron micrographs. Comparison of interstitial, basement membrane and intima collagens. J Mol Biol (1984) 172:325-43. doi:10.1016/S0022-2836(84)80029-7

20. Hudson BG, Tryggvason K, Sundaramoorthy M, Neilson EG. Alport's syndrome, Goodpasture's syndrome, and type IV collagen. N Engl J Med (2003) 348:2543-56. doi:10.1056/NEJMra022296

21. Hudson BG. The molecular basis of Goodpasture and Alport syndromes: beacons for the discovery of the collagen IV family. J Am Soc Nephrol (2004) 15:2514-27. doi:10.1097/01.ASN.0000141462.00630.76

22. Miner JH. Developmental biology of glomerular basement membrane components. Curr Opin Nephrol Hypertens (1998) 7:13-9. doi:10.1097/ 00041552-199801000-00003

23. Miner JH. Renal basement membrane components. Kidney Int (1999) 56:2016-24. doi:10.1046/j.1523-1755.1999.00785.x

24. Ninomiya Y, Kagawa M, Iyama K, Naito I, Kishiro Y, Seyer JM, et al. Differential expression of two basement membrane collagen genes, COL4A6 and COL4A5, demonstrated by immunofluorescence staining using peptidespecific monoclonal antibodies. J Cell Biol (1995) 130:1219-29. doi:10.1083/ jcb.130.5.1219

25. Kalluri R, Shield CF, Todd P, Hudson BG, Neilson EG. Isoform switching of type IV collagen is developmentally arrested in X-linked Alport syndrome leading to increased susceptibility of renal basement membranes to endoproteolysis. J Clin Invest (1997) 99:2470-8. doi:10.1172/JCI119431

26. Yurchenco PD, Ruben GC. Basement membrane structure in situ: evidence for lateral associations in the type IV collagen network. J Cell Biol (1987) 105:2559-68. doi:10.1083/jcb.105.6.2559

27. Kashtan CE, Kim Y. Distribution of the alpha 1 and alpha 2 chains of collagen IV and of collagens V and VI in Alport syndrome. Kidney Int (1992) 42:115-26. doi:10.1038/ki.1992.269

28. Miner JH. The glomerular basement membrane. Exp Cell Res (2012) 318:973-8. doi:10.1016/j.yexcr.2012.02.031

29. Savige J, Gregory M, Gross O, Kashtan C, Ding J, Flinter F. Expert guidelines for the management of Alport syndrome and thin basement membrane nephropathy. J Am Soc Nephrol (2013) 24:364-75. doi:10.1681/ ASN.2012020148

30. Jais JP, Knebelmann B, Giatras I, De Marchi M, Rizzoni G, Renieri A, et al. X-linked Alport syndrome: natural history in 195 families and genotypephenotype correlations in males. J Am Soc Nephrol (2000) 11:649-57.

31. Gross O, Kashtan CE, Rheault MN, Flinter F, Savige J, Miner JH, et al. Advances and unmet needs in genetic, basic and clinical science in Alport syndrome: report from the 2015 International Workshop on Alport syndrome. Nephrol Dial Transplant (2017) 32:916-24. doi:10.1093/ndt/gfw095

32. Savige J, Colville D. Opinion: ocular features aid the diagnosis of Alport syndrome. Nat Rev Nephrol (2009) 5:356-60. doi:10.1038/nrneph.2009.65

33. Noone D, Licht C. An update on the pathomechanisms and future therapies of Alport syndrome. Pediatr Nephrol (2013) 28:1025-36. doi:10.1007/ s00467-012-2272-z

34. Heidet L, Arrondel C, Forestier L, Cohen-Solal L, Mollet G, Gutierrez B, et al. Structure of the human type IV collagen gene COL4A3 and mutations in autosomal Alport syndrome. J Am Soc Nephrol (2001) 12:97-106.

35. Pescucci C, Mari F, Longo I, Vogiatzi P, Caselli R, Scala E, et al. Autosomal-dominant Alport syndrome: natural history of a disease due to
COL4A3 or COL4A4 gene. Kidney Int (2004) 65:1598-603. doi:10.1111/j. 1523-1755.2004.00560.x

36. Jais JP, Knebelmann B, Giatras I, De Marchi M, Rizzoni G, Renieri A, et al. X-linked Alport syndrome: natural history and genotype-phenotype correlations in girls and women belonging to 195 families: a "European Community Alport Syndrome Concerted Action" study. J Am Soc Nephrol (2003) 14:2603-10. doi:10.1097/01.ASN.0000090034.71205.74

37. Bekheirnia MR, Reed B, Gregory MC, McFann K, Shamshirsaz AA, Masoumi A, et al. Genotype-phenotype correlation in X-linked Alport syndrome. J Am Soc Nephrol (2010) 21:876-83. doi:10.1681/ASN.2009070784

38. Rheault MN, Kren SM, Hartich LA, Wall M, Thomas W, Mesa HA, et al. $\mathrm{X}$-inactivation modifies disease severity in female carriers of murine $\mathrm{X}$-linked Alport syndrome. Nephrol Dial Transplant (2010) 25:764-9. doi:10.1093/ndt/ gfp551

39. Kashtan CE, Kim Y, Lees GE, Thorner PS, Virtanen I, Miner JH. Abnormal glomerular basement membrane laminins in murine, canine, and human Alport syndrome: aberrant laminin alpha2 deposition is species independent. J Am Soc Nephrol (2001) 12:252-60.

40. Staatz WD, Walsh JJ, Pexton T, Santoro SA. The alpha 2 beta 1 integrin cell surface collagen receptor binds to the alpha 1 (I)-CB3 peptide of collagen. J Biol Chem (1990) 265:4778-81.

41. Mohan RR, Mohan RR, Wilson SE. Discoidin domain receptor (DDR) 1 and 2: collagen-activated tyrosine kinase receptors in the cornea. Exp Eye Res (2001) 72:87-92. doi:10.1006/exer.2000.0932

42. Lemmon MA, Schlessinger J. Cell signaling by receptor tyrosine kinases. Cell (2010) 141:1117-34. doi:10.1016/j.cell.2010.06.011

43. Shrivastava A, Radziejewski C, Campbell E, Kovac L, McGlynn M, Ryan TE, et al. An orphan receptor tyrosine kinase family whose members serve as nonintegrin collagen receptors. Mol Cell (1997) 1:25-34. doi:10.1016/ S1097-2765(00)80004-0

44. Vogel WF, Aszodi A, Alves F, Pawson T. Discoidin domain receptor 1 tyrosine kinase has an essential role in mammary gland development. Mol Cell Biol (2001) 21:2906-17. doi:10.1128/MCB.21.8.2906-2917.2001

45. Kadler KE, Baldock C, Bella J, Boot-Handford RP. Collagens at a glance. J Cell Sci (2007) 120:1955-8. doi:10.1242/jcs.03453

46. Gross O, Beirowski B, Harvey SJ, McFadden C, Chen D, Tam S, et al. DDR1-deficient mice show localized subepithelial GBM thickening with focal loss of slit diaphragms and proteinuria. Kidney Int (2004) 66:102-11. doi:10.1111/j.1523-1755.2004.00712.x

47. Girgert R, Martin M, Kruegel J, Miosge N, Temme J, Eckes B, et al. Integrin alpha2-deficient mice provide insights into specific functions of collagen receptors in the kidney. Fibrogenesis Tissue Repair (2010) 3:19. doi:10.1186/1755-1536-3-19

48. Gross O, Girgert R, Beirowski B, Kretzler M, Kang HG, Kruegel J, et al. Loss of collagen-receptor DDR1 delays renal fibrosis in hereditary type IV collagen disease. Matrix Biol (2010) 29:346-56. doi:10.1016/j.matbio.2010.03.002

49. Meehan DT, Delimont D, Cheung L, Zallocchi M, Sansom SC, Holzclaw JD, et al. Biomechanical strain causes maladaptive gene regulation, contributing to Alport glomerular disease. Kidney Int (2009) 76:968-76. doi:10.1038/ ki.2009.324

50. Gross O, Beirowski B, Koepke ML, Kuck J, Reiner M, Addicks K, et al. Preemptive ramipril therapy delays renal failure and reduces renal fibrosis in COL4A3-knockout mice with Alport syndrome. Kidney Int (2003) 63:438-46. doi:10.1046/j.1523-1755.2003.00779.x

51. Gross O, Licht C, Anders HJ, Hoppe B, Beck B, Tonshoff B, et al. Early angiotensin-converting enzyme inhibition in Alport syndrome delays renal failure and improves life expectancy. Kidney Int (2012) 81:494-501. doi:10.1038/ki.2011.407

52. Dufek B, Meehan DT, Delimont D, Cheung L, Gratton MA, Phillips G, et al. Endothelin A receptor activation on mesangial cells initiates Alport glomerular disease. Kidney Int (2016) 90:300-10. doi:10.1016/j.kint.2016.02.018

53. Lammerding J, Kazarov AR, Huang H, Lee RT, Hemler ME. Tetraspanin CD151 regulates alpha6beta1 integrin adhesion strengthening. Proc Natl Acad Sci U S A (2003) 100:7616-21. doi:10.1073/pnas.1337546100

54. Delimont D, Dufek BM, Meehan DT, Zallocchi M, Gratton MA, Phillips G, et al. Laminin alpha2-mediated focal adhesion kinase activation triggers Alport glomerular pathogenesis. PLoS One (2014) 9:e99083. doi:10.1371/journal.pone.0099083 
55. Zeisberg M, Khurana M, Rao VH, Cosgrove D, Rougier JP, Werner MC, et al. Stage-specific action of matrix metalloproteinases influences progressive hereditary kidney disease. PLoS Med (2006) 3:e100. doi:10.1371/journal. pmed.0030100

56. Rao VH, Meehan DT, Delimont D, Nakajima M, Wada T, Gratton MA, et al. Role for macrophage metalloelastase in glomerular basement membrane damage associated with alport syndrome. Am J Pathol (2006) 169:32-46. doi:10.2353/ajpath.2006.050896

57. Cosgrove D, Rodgers K, Meehan D, Miller C, Bovard K, Gilroy A, et al. Integrin alpha1beta1 and transforming growth factor-betal play distinct roles in alport glomerular pathogenesis and serve as dual targets for metabolic therapy. Am J Pathol (2000) 157:1649-59. doi:10.1016/S0002-9440(10)64802-X

58. Sayers R, Kalluri R, Rodgers KD, Shield CF, Meehan DT, Cosgrove D. Role for transforming growth factor-betal in alport renal disease progression. Kidney Int (1999) 56:1662-73. doi:10.1046/j.1523-1755.1999.00744.x

59. Proesmans W, Van Dyck M. Enalapril in children with Alport syndrome. Pediatr Nephrol (2004) 19:271-5. doi:10.1007/s00467-003-1366-Z

60. Gross O, Friede T, Hilgers R, Gorlitz A, Gavenis K, Ahmed R, et al. Safety and efficacy of the ACE-inhibitor ramipril in Alport syndrome: the double-blind, randomized, placebo-controlled, multicenter phase III EARLY PRO-TECT Alport trial in pediatric patients. ISRN Pediatr (2012) 2012:436046. doi:10.5402/2012/436046

61. Miner JH, Baigent C, Flinter F, Gross O, Judge P, Kashtan CE, et al. The 2014 international workshop on Alport syndrome. Kidney Int (2014) 86:679-84. doi:10.1038/ki.2014.229

62. Kashtan CE, McEnery PT, Tejani A, Stablein DM. Renal allograft survival according to primary diagnosis: a report of the North American pediatric renal transplant cooperative study. Pediatr Nephrol (1995) 9:679-84. doi:10.1007/BF00868709

63. Kashtan CE. Renal transplantation in patients with Alport syndrome. Pediatr Transplant (2006) 10:651-7. doi:10.1111/j.1399-3046.2006.00528.x

64. Gross O, Weber M, Fries JW, Muller GA. Living donor kidney transplantation from relatives with mild urinary abnormalities in Alport syndrome: longterm risk, benefit and outcome. Nephrol Dial Transplant (2009) 24:1626-30. doi:10.1093/ndt/gfn635

65. Browne G, Brown PA, Tomson CR, Fleming S, Allen A, Herriot R, et al. Retransplantation in Alport post-transplant anti-GBM disease. Kidney Int (2004) 65:675-81. doi:10.1111/j.1523-1755.2004.00428.x

66. Ding J, Zhou J, Tryggvason K, Kashtan CE. COL4A5 deletions in three patients with Alport syndrome and posttransplant antiglomerular basement membrane nephritis. J Am Soc Nephrol (1994) 5:161-8.

67. Brainwood D, Kashtan C, Gubler MC, Turner AN. Targets of alloantibodies in Alport anti-glomerular basement membrane disease after renal transplantation. Kidney Int (1998) 53:762-6. doi:10.1046/j.1523-1755.1998.00794.x

68. Lin X, Suh JH, Go G, Miner JH. Feasibility of repairing glomerular basement membrane defects in Alport syndrome. J Am Soc Nephrol (2014) 25:687-92. doi:10.1681/ASN.2013070798

69. Sugimoto H, Mundel TM, Sund M, Xie L, Cosgrove D, Kalluri R. Bonemarrow-derived stem cells repair basement membrane collagen defects and reverse genetic kidney disease. Proc Natl Acad Sci U S A (2006) 103:7321-6. doi:10.1073/pnas.0601436103

70. Savige J, Rana K, Tonna S, Buzza M, Dagher H, Wang YY. Thin basement membrane nephropathy. Kidney Int (2003) 64:1169-78. doi:10.1046/j. 1523-1755.2003.00234.x

71. Rana K, Wang YY, Buzza M, Tonna S, Zhang KW, Lin T, et al. The genetics of thin basement membrane nephropathy. Semin Nephrol (2005) 25:163-70. doi:10.1016/j.semnephrol.2005.01.008

72. Buzza M, Wilson D, Savige J. Segregation of hematuria in thin basement membrane disease with haplotypes at the loci for Alport syndrome. Kidney Int (2001) 59:1670-6. doi:10.1046/j.1523-1755.2001.0590051670.x

73. Voskarides K, Damianou L, Neocleous V, Zouvani I, Christodoulidou S, Hadjiconstantinou V, et al. COL4A3/COL4A4 mutations producing focal segmental glomerulosclerosis and renal failure in thin basement membrane nephropathy. JAm Soc Nephrol (2007) 18:3004-16. doi:10.1681/ ASN.2007040444

74. Plaisier E, Alamowitch S, Gribouval O, Mougenot B, Gaudric A, Antignac C, et al. Autosomal-dominant familial hematuria with retinal arteriolar tortuosity and contractures: a novel syndrome. Kidney Int (2005) 67:2354-60. doi:10.1111/j.1523-1755.2005.00341.x
75. Plaisier E, Chen Z, Gekeler F, Benhassine S, Dahan K, Marro B, et al. Novel COL4A1 mutations associated with HANAC syndrome: a role for the triple helical CB3[IV] domain. Am J Med Genet A (2010) 152A:2550-5. doi:10.1002/ajmg.a.33659

76. Alamowitch S, Plaisier E, Favrole P, Prost C, Chen Z, Van Agtmael T, et al. Cerebrovascular disease related to COL4A1 mutations in HANAC syndrome. Neurology (2009) 73:1873-82. doi:10.1212/WNL.0b013e3181c3fd12

77. Breedveld G, de Coo IF, Lequin MH, Arts WF, Heutink P, Gould DB, et al. Novel mutations in three families confirm a major role of COL4A1 in hereditary porencephaly. JMed Genet (2006) 43:490-5. doi:10.1136/ jmg.2005.035584

78. Gould DB, Phalan FC, van Mil SE, Sundberg JP, Vahedi K, Massin P, et al. Role of COL4A1 in small-vessel disease and hemorrhagic stroke. $N$ Engl J Med (2006) 354:1489-96. doi:10.1056/NEJMoa053727

79. Plaisier E, Gribouval O, Alamowitch S, Mougenot B, Prost C, Verpont MC, et al. COL4A1 mutations and hereditary angiopathy, nephropathy, aneurysms, and muscle cramps. N Engl J Med (2007) 357:2687-95. doi:10.1056/ NEJMoa071906

80. Chen Z, Migeon T, Verpont MC, Zaidan M, Sado Y, Kerjaschki D, et al. Col4a1 mutation causes neonate glomerular hyperpermeability and adult glomerulocystic kidney disease. JAm Soc Nephrol (2016) 27:1042-54. doi:10.1681/ASN.2014121217

81. McKee KK, Harrison D, Capizzi S, Yurchenco PD. Role of laminin terminal globular domains in basement membrane assembly. J Biol Chem (2007) 282:21437-47. doi:10.1074/jbc.M702963200

82. Miner JH, Yurchenco PD. Laminin functions in tissue morphogenesis. Annu Rev Cell Dev Biol (2004) 20:255-84. doi:10.1146/annurev.cellbio. 20.010403.094555

83. Paulsson M. Basement membrane proteins: structure, assembly, and cellular interactions. Crit Rev Biochem Mol Biol (1992) 27:93-127. doi:10.3109/ 10409239209082560

84. Aumailley M, Bruckner-Tuderman L, Carter WG, Deutzmann R, Edgar D, Ekblom P, et al. A simplified laminin nomenclature. Matrix Biol (2005) 24:326-32. doi:10.1016/j.matbio.2005.05.006

85. Miner JH, Sanes JR. Collagen IV alpha 3, alpha 4, and alpha 5 chains in rodent basal laminae: sequence, distribution, association with laminins, and developmental switches. J Cell Biol (1994) 127:879-91. doi:10.1083/jcb.127.3.879

86. Ekblom P, Timpl R. Cell-to-cell contact and extracellular matrix. A multifaceted approach emerging. Curr Opin Cell Biol (1996) 8:599-601. doi:10.1016/ S0955-0674(96)80099-8

87. Yurchenco PD, Cheng YS. Self-assembly and calcium-binding sites in laminin. A three-arm interaction model. J Biol Chem (1993) 268:17286-99.

88. Cheng YS, Champliaud MF, Burgeson RE, Marinkovich MP, Yurchenco PD. Self-assembly of laminin isoforms. J Biol Chem (1997) 272:31525-32. doi:10.1074/jbc.272.50.31525

89. Colognato H, Winkelmann DA, Yurchenco PD. Laminin polymerization induces a receptor-cytoskeleton network. JCell Biol (1999) 145:619-31. doi:10.1083/jcb.145.3.619

90. Colognato H, Yurchenco PD. Form and function: the laminin family of heterotrimers. Dev Dyn (2000) 218:213-34. doi:10.1002/(SICI)1097-0177(200006) 218:2<213::AID-DVDY1>3.0.CO;2-R

91. Henry MD, Campbell KP. Dystroglycan inside and out. Curr Opin Cell Biol (1999) 11:602-7. doi:10.1016/S0955-0674(99)00024-1

92. Kikkawa Y, Virtanen I, Miner JH. Mesangial cells organize the glomerular capillaries by adhering to the $\mathrm{G}$ domain of laminin alpha5 in the glomerular basement membrane. J Cell Biol (2003) 161:187-96. doi:10.1083/jcb. 200211121

93. Kreidberg JA, Donovan MJ, Goldstein SL, Rennke H, Shepherd K, Jones RC, et al. Alpha 3 beta 1 integrin has a crucial role in kidney and lung organogenesis. Development (1996) 122:3537-47.

94. Ervasti JM, Campbell KP. A role for the dystrophin-glycoprotein complex as a transmembrane linker between laminin and actin. J Cell Biol (1993) 122:809-23. doi:10.1083/jcb.122.4.809

95. Raats CJ, van den Born J, Bakker MA, Oppers-Walgreen B, Pisa BJ, Dijkman HB, et al. Expression of agrin, dystroglycan, and utrophin in normal renal tissue and in experimental glomerulopathies. Am J Pathol (2000) 156:1749-65. doi:10.1016/S0002-9440(10)65046-8

96. Kojima K, Davidovits A, Poczewski H, Langer B, Uchida S, Nagy-Bojarski K, et al. Podocyte flattening and disorder of glomerular basement membrane 
are associated with splitting of dystroglycan-matrix interaction. J Am Soc Nephrol (2004) 15:2079-89. doi:10.1097/01.ASN.0000133531.43177.21

97. Jarad G, Pippin JW, Shankland SJ, Kreidberg JA, Miner JH. Dystroglycan does not contribute significantly to kidney development or function, in health or after injury. Am J Physiol Renal Physiol (2011) 300:F811-20. doi:10.1152/ ajprenal.00725.2010

98. Wizemann H, Garbe JH, Friedrich MV, Timpl R, Sasaki T, Hohenester E. Distinct requirements for heparin and alpha-dystroglycan binding revealed by structure-based mutagenesis of the laminin alpha2 LG4-LG5 domain pair. J Mol Biol (2003) 332:635-42. doi:10.1016/S0022-2836(03)00848-9

99. Kojima K, Nosaka H, Kishimoto Y, Nishiyama Y, Fukuda S, Shimada M, et al. Defective glycosylation of alpha-dystroglycan contributes to podocyte flattening. Kidney Int (2011) 79:311-6. doi:10.1038/ki.2010.403

100. Pierson M, Cordier J, Hervouuet F, Rauber G. [An unusual congenital and familial congenital malformative combination involving the eye and kidney]. J Genet Hum (1963) 12:184-213.

101. Zenker M, Tralau T, Lennert T, Pitz S, Mark K, Madlon H, et al. Congenital nephrosis, mesangial sclerosis, and distinct eye abnormalities with microcoria: an autosomal recessive syndrome. Am J Med Genet A (2004) 130A:138-45. doi:10.1002/ajmg.a.30310

102. Chen YM, Miner JH. Glomerular basement membrane and related glomerular disease. Transl Res (2012) 160:291-7. doi:10.1016/j.trsl.2012.03.004

103. Bredrup C, Matejas V, Barrow M, Blahova K, Bockenhauer D, Fowler DJ, et al. Ophthalmological aspects of Pierson syndrome. Am JOphthalmol (2008) 146:602-11. doi:10.1016/j.ajo.2008.05.039

104. Hasselbacher K, Wiggins RC, Matejas V, Hinkes BG, Mucha B, Hoskins BE, et al. Recessive missense mutations in LAMB2 expand the clinical spectrum of LAMB2-associated disorders. Kidney Int (2006) 70:1008-12. doi:10.1038/ sj.ki.5001679

105. Maselli RA, Ng JJ, Anderson JA, Cagney O, Arredondo J, Williams C, et al. Mutations in LAMB2 causing a severe form of synaptic congenital myasthenic syndrome. J Med Genet (2009) 46:203-8. doi:10.1136/jmg.2008.063693

106. Zenker M, Aigner T, Wendler O, Tralau T, Muntefering H, Fenski R, et al. Human laminin beta2 deficiency causes congenital nephrosis with mesangial sclerosis and distinct eye abnormalities. Hum Mol Genet (2004) 13:2625-32. doi: $10.1093 / \mathrm{hmg} / \mathrm{ddh} 284$

107. Noakes PG, Miner JH, Gautam M, Cunningham JM, Sanes JR, Merlie JP. The renal glomerulus of mice lacking s-laminin/laminin beta 2: nephrosis despite molecular compensation by laminin beta 1 . Nat Genet (1995) 10:400-6. doi:10.1038/ng0895-400

108. Noakes PG, Gautam M, Mudd J, Sanes JR, Merlie JP. Aberrant differentiation of neuromuscular junctions in mice lacking s-laminin/laminin beta 2. Nature (1995) 374:258-62. doi:10.1038/374258a0

109. Jarad G, Cunningham J, Shaw AS, Miner JH. Proteinuria precedes podocyte abnormalities in Lamb2-/- mice, implicating the glomerular basement membrane as an albumin barrier. JClin Invest (2006) 116:2272-9. doi:10.1172/ JCI28414

110. Miner JH, Go G, Cunningham J, Patton BL, Jarad G. Transgenic isolation of skeletal muscle and kidney defects in laminin beta2 mutant mice: implications for Pierson syndrome. Development (2006) 133:967-75. doi:10.1242/ dev. 02270

111. Suh JH, Jarad G, VanDeVoorde RG, Miner JH. Forced expression of laminin betal in podocytes prevents nephrotic syndrome in mice lacking laminin beta2, a model for Pierson syndrome. Proc Natl Acad Sci U S A (2011) 108:15348-53. doi:10.1073/pnas.1108269108

112. Kohfeldt E, Sasaki T, Gohring W, Timpl R. Nidogen-2: a new basement membrane protein with diverse binding properties. J Mol Biol (1998) 282:99-109. doi:10.1006/jmbi.1998.2004

113. Salmivirta K, Talts JF, Olsson M, Sasaki T, Timpl R, Ekblom P. Binding of mouse nidogen-2 to basement membrane components and cells and its expression in embryonic and adult tissues suggest complementary functions of the two nidogens. Exp Cell Res (2002) 279:188-201. doi:10.1006/ excr.2002.5611

114. Timpl R. Structure and biological activity of basement membrane proteins. Eur J Biochem (1989) 180:487-502. doi:10.1111/j.1432-1033.1989.tb14673.x

115. Murshed M, Smyth N, Miosge N, Karolat J, Krieg T, Paulsson M, et al. The absence of nidogen 1 does not affect murine basement membrane formation. Mol Cell Biol (2000) 20:7007-12. doi:10.1128/MCB.20.18.70077012.2000
116. Schymeinsky J, Nedbal S, Miosge N, Poschl E, Rao C, Beier DR, et al. Gene structure and functional analysis of the mouse nidogen-2 gene: nidogen-2 is not essential for basement membrane formation in mice. Mol Cell Biol (2002) 22:6820-30. doi:10.1128/MCB.22.19.6820-6830.2002

117. Amann K, Haas CS, Zeiler GA, Benz K, Bader BL, Hartner A, et al. Lack of nidogen-2 increases blood pressure, glomerular and tubulointerstitial damage in DOCA-salt hypertension. Eur J Clin Invest (2009) 39:116-25. doi:10.1111/j.1365-2362.2008.02065.x

118. Aleckovic M, Wei Y, LeRoy G, Sidoli S, Liu DD, Garcia BA, et al. Identification of Nidogen 1 as a lung metastasis protein through secretome analysis. Genes Dev (2017) 31:1439-55. doi:10.1101/gad.301937.117

119. Groffen AJ, Veerkamp JH, Monnens LA, van den Heuvel LP. Recent insights into the structure and functions of heparan sulfate proteoglycans in the human glomerular basement membrane. Nephrol Dial Transplant (1999) 14:2119-29. doi:10.1093/ndt/14.9.2119

120. Saarela J, Rehn M, Oikarinen A, Autio-Harmainen H, Pihlajaniemi T. The short and long forms of type XVIII collagen show clear tissue specificities in their expression and location in basement membrane zones in humans. Am J Pathol (1998) 153:611-26. doi:10.1016/S0002-9440(10)65603-9

121. Kallunki P, Tryggvason K. Human basement membrane heparan sulfate proteoglycan core protein: a $467-\mathrm{kD}$ protein containing multiple domains resembling elements of the low density lipoprotein receptor, laminin, neural cell adhesion molecules, and epidermal growth factor. J Cell Biol (1992) 116:559-71. doi:10.1083/jcb.116.2.559

122. Timpl R, Brown JC. Supramolecular assembly of basement membranes. Bioessays (1996) 18:123-32. doi:10.1002/bies.950180208

123. Groffen AJ, Hop FW, Tryggvason K, Dijkman H, Assmann KJ, Veerkamp JH, et al. Evidence for the existence of multiple heparan sulfate proteoglycans in the human glomerular basement membrane and mesangial matrix. Eur J Biochem (1997) 247:175-82. doi:10.1111/j.1432-1033.1997.00175.x

124. Rossi M, Morita H, Sormunen R, Airenne S, Kreivi M, Wang L, et al. Heparan sulfate chains of perlecan are indispensable in the lens capsule but not in the kidney. EMBO J (2003) 22:236-45. doi:10.1093/emboj/cdg019

125. Morita $\mathrm{H}$, Yoshimura $\mathrm{A}$, Inui $\mathrm{K}$, Ideura $\mathrm{T}$, Watanabe $\mathrm{H}$, Wang $\mathrm{L}$, et al. Heparan sulfate of perlecan is involved in glomerular filtration. J Am Soc Nephrol (2005) 16:1703-10. doi:10.1681/ASN.2004050387

126. Utriainen A, Sormunen R, Kettunen M, Carvalhaes LS, Sajanti E, Eklund L, et al. Structurally altered basement membranes and hydrocephalus in a type XVIII collagen deficient mouse line. Hum Mol Genet (2004) 13:2089-99. doi:10.1093/hmg/ddh213

127. Suleiman H, Zhang L, Roth R, Heuser JE, Miner JH, Shaw AS, et al. Nanoscale protein architecture of the kidney glomerular basement membrane. Elife (2013) 2:e01149. doi:10.7554/eLife.01149

128. Rennke HG, Cotran RS, Venkatachalam MA. Role of molecular charge in glomerular permeability. Tracer studies with cationized ferritins. J Cell Biol (1975) 67:638-46. doi:10.1083/jcb.67.3.638

129. Bezakova G, Ruegg MA. New insights into the roles of agrin. Nat Rev Mol Cell Biol (2003) 4:295-308. doi:10.1038/nrm1074

130. Goldberg S, Harvey SJ, Cunningham J, Tryggvason K, Miner JH. Glomerular filtration is normal in the absence of both agrin and perlecan-heparan sulfate from the glomerular basement membrane. Nephrol Dial Transplant (2009) 24:2044-51. doi:10.1093/ndt/gfn758

131. van den Born J, van den Heuvel LP, Bakker MA, Veerkamp JH, Assmann KJ, Weening JJ, et al. Distribution of GBM heparan sulfate proteoglycan core protein and side chains in human glomerular diseases. Kidney Int (1993) 43:454-63. doi:10.1038/ki.1993.67

132. Smith RJ, Alexander J, Barlow PN, Botto M, Cassavant TL, Cook HT, et al. New approaches to the treatment of dense deposit disease. J Am Soc Nephrol (2007) 18:2447-56. doi:10.1681/ASN.2007030356

133. van den Heuvel LP, Westenend PJ, van den Born J, Assmann KJ, Knoers N, Monnens LA. Aberrant proteoglycan composition of the glomerular basement membrane in a patient with Denys-Drash syndrome. Nephrol Dial Transplant (1995) 10:2205-11. doi:10.1093/ndt/10.12.2205

134. van Bruggen MC, Kramers K, Hylkema MN, van den Born J, Bakker MA, Assmann KJ, et al. Decrease of heparan sulfate staining in the glomerular basement membrane in murine lupus nephritis. Am J Pathol (1995) 146:753-63.

135. Raats CJ, Luca ME, Bakker MA, Van Der Wal A, Heeringa P, Van Goor H, et al. Reduction in glomerular heparan sulfate correlates with complement 
deposition and albuminuria in active Heymann nephritis. J Am Soc Nephrol (1999) 10:1689-99.

136. van den Born J, van Kraats AA, Bakker MA, Assmann KJ, van den Heuvel LP, Veerkamp $\mathrm{JH}$, et al. Selective proteinuria in diabetic nephropathy in the rat is associated with a relative decrease in glomerular basement membrane heparan sulphate. Diabetologia (1995) 38:161-72. doi:10.1007/ BF00422365

137. Peterson SB, Liu J. Multi-faceted substrate specificity of heparanase. Matrix Biol (2013) 32:223-7. doi:10.1016/j.matbio.2013.02.006

138. Levidiotis V, Freeman C, Tikellis C, Cooper ME, Power DA. Heparanase inhibition reduces proteinuria in a model of accelerated anti-glomerular basement membrane antibody disease. Nephrology (Carlton) (2005) 10:167-73. doi:10.1111/j.1440-1797.2005.00388.x

139. Rops AL, van den Hoven MJ, Bakker MA, Lensen JF, Wijnhoven TJ, van den Heuvel LP, et al. Expression of glomerular heparan sulphate domains in murine and human lupus nephritis. Nephrol Dial Transplant (2007) 22:1891-902. doi:10.1093/ndt/gfm530

140. Sato N, Ohsawa I,NagamachiS, Ishii M, Kusaba G, Inoshita H, et al. Significance of glomerular activation of the alternative pathway and lectin pathway in lupus nephritis. Lupus (2011) 20:1378-86. doi:10.1177/0961203311415561

141. Ma R, Cui Z, Hu SY, Jia XY, Yang R, Zheng X, et al. The alternative pathway of complement activation may be involved in the renal damage of human anti-glomerular basement membrane disease. PLoS One (2014) 9:e91250. doi:10.1371/journal.pone.0091250

142. Humphries MJ, Travis MA, Clark K, Mould AP. Mechanisms of integration of cells and extracellular matrices by integrins. Biochem Soc Trans (2004) 32:822-5. doi:10.1042/BST0320822

143. Petersen TE, Thogersen HC, Skorstengaard K, Vibe-Pedersen K, Sahl P, Sottrup-Jensen L, et al. Partial primary structure of bovine plasma fibronectin: three types of internal homology. Proc Natl Acad Sci U S A (1983) 80:137-41. doi:10.1073/pnas.80.1.137

144. Leahy DJ, Hendrickson WA, Aukhil I, Erickson HP. Structure of a fibronectin type III domain from tenascin phased by MAD analysis of the selenomethionyl protein. Science (1992) 258:987-91. doi:10.1126/science.1279805

145. Leahy DJ, Aukhil I, Erickson HP. 2.0 A crystal structure of a four-domain segment of human fibronectin encompassing the RGD loop and synergy region. Cell (1996) 84:155-64. doi:10.1016/S0092-8674(00)81002-8

146. Tamkun JW, Hynes RO. Plasma fibronectin is synthesized and secreted by hepatocytes. J Biol Chem (1983) 258:4641-7.

147. Moretti FA, Chauhan AK, Iaconcig A, Porro F, Baralle FE, Muro AF. A major fraction of fibronectin present in the extracellular matrix of tissues is plasmaderived. J Biol Chem (2007) 282:28057-62. doi:10.1074/jbc.M611315200

148. Wu C, Keivens VM, O’Toole TE, McDonald JA, Ginsberg MH. Integrin activation and cytoskeletal interaction are essential for the assembly of a fibronectin matrix. Cell (1995) 83:715-24. doi:10.1016/0092-8674(95)90184-1

149. Kubow KE, Vukmirovic R, Zhe L, Klotzsch E, Smith ML, Gourdon D, et al. Mechanical forces regulate the interactions of fibronectin and collagen I in extracellular matrix. Nat Commun (2015) 6:8026. doi:10.1038/ncomms9026

150. Liu S, Shi L, Wang S. Overexpression of upstream stimulatory factor 2 accelerates diabetic kidney injury. Am J Physiol Renal Physiol (2007) 293:F1727-35. doi:10.1152/ajprenal.00316.2007

151. Strom EH, Banfi G, Krapf R, Abt AB, Mazzucco G, Monga G, et al. Glomerulopathy associated with predominant fibronectin deposits: a newly recognized hereditary disease. Kidney Int (1995) 48:163-70. doi:10.1038/ki. 1995.280

152. Yung S, Zhang Q, Zhang CZ, Chan KW, Lui SL, Chan TM. Anti-DNA antibody induction of protein kinase $\mathrm{C}$ phosphorylation and fibronectin synthesis in human and murine lupus and the effect of mycophenolic acid. Arthritis Rheum (2009) 60:2071-82. doi:10.1002/art.24573

153. Satoskar AA, Shapiro JP, Bott CN, Song H, Nadasdy GM, Brodsky SV, et al. Characterization of glomerular diseases using proteomic analysis of laser capture microdissected glomeruli. Mod Pathol (2012) 25:709-21. doi:10.1038/modpathol.2011.205

154. Castelletti F, Donadelli R, Banterla F, Hildebrandt F, Zipfel PF, Bresin E, et al. Mutations in FN1 cause glomerulopathy with fibronectin deposits. Proc Natl Acad Sci U S A (2008) 105:2538-43. doi:10.1073/pnas.0707730105

155. Dreyer SD, Zhou G, Baldini A, Winterpacht A, Zabel B, Cole W, et al. Mutations in LMX1B cause abnormal skeletal patterning and renal dysplasia in nail patella syndrome. Nat Genet (1998) 19:47-50. doi:10.1038/ng0598-47
156. Morello R, Zhou G, Dreyer SD, Harvey SJ, Ninomiya Y, Thorner PS, et al. Regulation of glomerular basement membrane collagen expression by LMX1B contributes to renal disease in nail patella syndrome. Nat Genet (2001) 27:205-8. doi:10.1038/84853

157. Mino RA, Mino VH, Livingstone RG. Osseous dysplasia and dystrophy of the nails; review of the literature and report of a case. Am J Roentgenol Radium Ther (1948) 60:633-41.

158. Bennett WM, Musgrave JE, Campbell RA, Elliot D, Cox R, Brooks RE, et al. The nephropathy of the nail-patella syndrome. Clinicopathologic analysis of 11 kindred. Am J Med (1973) 54:304-19. doi:10.1016/0002-9343(73)90025-9

159. Lemley KV. Kidney disease in nail-patella syndrome. Pediatr Nephrol (2009) 24:2345-54. doi:10.1007/s00467-008-0836-8

160. Vollrath D, Jaramillo-Babb VL, Clough MV, McIntosh I, Scott KM, Lichter PR, et al. Loss-of-function mutations in the LIM-homeodomain gene, LMX1B, in nail-patella syndrome. Hum Mol Genet (1998) 7:1091-8. doi:10.1093/hmg/7.7.1091

161. Bongers EM, Huysmans FT, Levtchenko E, de Rooy JW, Blickman JG, Admiraal RJ, et al. Genotype-phenotype studies in nail-patella syndrome show that LMX1B mutation location is involved in the risk of developing nephropathy. EurJ Hum Genet (2005) 13:935-46. doi:10.1038/sj.ejhg.5201446

162. Kolhe N, Stoves J, Will EJ, Hartley B. Nail-patella syndrome - renal and musculo-skeletal features. Nephrol Dial Transplant (2002) 17:169-70. doi:10.1093/ndt/17.1.169

163. Peterson LC, Rao KV, Crosson JT, White JG. Fechtner syndrome - a variant of Alport's syndrome with leukocyte inclusions and macrothrombocytopenia. Blood (1985) 65:397-406.

164. Naito I, Nomura S, Inoue S, Kagawa M, Kawai S, Gunshin Y, et al. Normal distribution of collagen IV in renal basement membranes in Epstein's syndrome. J Clin Pathol (1997) 50:919-22. doi:10.1136/jcp.50.11.919

165. Epstein CJ, Sahud MA, Piel CF, Goodman JR, Bernfield MR, Kushner JH, et al. Hereditary macrothrombocytopathia, nephritis and deafness. Am J Med (1972) 52:299-310. doi:10.1016/0002-9343(72)90017-4

166. Pecci A, Panza E, Pujol-Moix N, Klersy C, Di Bari F, Bozzi V, et al. Position of nonmuscle myosin heavy chain IIA (NMMHC-IIA) mutations predicts the natural history of MYH9-related disease. Hum Mutat (2008) 29:409-17. doi:10.1002/humu.20661

167. Ghiggeri GM, Caridi G, Magrini U, Sessa A, Savoia A, Seri M, et al. Genetics, clinical and pathological features of glomerulonephritis associated with mutations of nonmuscle myosin IIA (Fechtner syndrome). Am J Kidney Dis (2003) 41:95-104. doi:10.1053/ajkd.2003.50028

168. Arrondel C, Vodovar N, Knebelmann B, Grunfeld JP, Gubler MC, Antignac C, et al. Expression of the nonmuscle myosin heavy chain IIA in the human kidney and screening for MYH9 mutations in Epstein and Fechtner syndromes. J Am Soc Nephrol (2002) 13:65-74.

169. Lennon R, Randles MJ, Humphries MJ. The importance of podocyte adhesion for a healthy glomerulus. Front Endocrinol (2014) 5:160. doi:10.3389/ fendo.2014.00160

170. Baraldi A, Furci L, Zambruno G, Rubbiani E, Annessi G, Lusvarghi E. Very late activation-3 integrin is the dominant beta 1-integrin on the glomerular capillary wall: an immunofluorescence study in nephrotic syndrome. Nephron (1992) 62:382-8. doi:10.1159/000187085

171. Sachs N, Kreft M, van den Bergh Weerman MA, Beynon AJ, Peters TA, Weening JJ, et al. Kidney failure in mice lacking the tetraspanin CD151. J Cell Biol (2006) 175:33-9. doi:10.1083/jcb.200603073

172. Has C, Sparta G, Kiritsi D, Weibel L, Moeller A, Vega-Warner V, et al. Integrin alpha3 mutations with kidney, lung, and skin disease. N Engl J Med (2012) 366:1508-14. doi:10.1056/NEJMoa1110813

173. Fassler R, Meyer M. Consequences of lack of beta 1 integrin gene expression in mice. Genes Dev (1995) 9:1896-908. doi:10.1101/gad.9.15.1896

174. Pozzi A, Jarad G, Moeckel GW, Coffa S, Zhang X, Gewin L, et al. Betal integrin expression by podocytes is required to maintain glomerular structural integrity. Dev Biol (2008) 316:288-301. doi:10.1016/j.ydbio.2008.01.022

175. Yauch RL, Berditchevski F, Harler MB, Reichner J, Hemler ME. Highly stoichiometric, stable, and specific association of integrin alpha3betal with CD151 provides a major link to phosphatidylinositol 4-kinase, and may regulate cell migration. Mol Biol Cell (1998) 9:2751-65. doi:10.1091/ mbc.9.10.2751

176. Baleato RM, Guthrie PL, Gubler MC, Ashman LK, Roselli S. Deletion of CD151 results in a strain-dependent glomerular disease due to severe 
alterations of the glomerular basement membrane. Am J Pathol (2008) 173:927-37. doi:10.2353/ajpath.2008.071149

177. Karamatic Crew V, Burton N, Kagan A, Green CA, Levene C, Flinter F, et al. CD151, the first member of the tetraspanin (TM4) superfamily detected on erythrocytes, is essential for the correct assembly of human basement membranes in kidney and skin. Blood (2004) 104:2217-23. doi:10.1182/ blood-2004-04-1512

178. Abrahamson DR, Leardkamolkarn V. Development of kidney tubular basement membranes. Kidney Int (1991) 39:382-93. doi:10.1038/ki. 1991.50

179. Miner JH, Li C. Defective glomerulogenesis in the absence of laminin alpha5 demonstrates a developmental role for the kidney glomerular basement membrane. Dev Biol (2000) 217:278-89. doi:10.1006/dbio.1999. 9546

180. Shannon MB, Patton BL, Harvey SJ, Miner JH. A hypomorphic mutation in the mouse laminin alpha5 gene causes polycystic kidney disease. J Am Soc Nephrol (2006) 17:1913-22. doi:10.1681/ASN.2005121298

181. Rao VH, Lees GE, Kashtan CE, Nemori R, Singh RK, Meehan DT, et al. Increased expression of MMP-2, MMP-9 (type IV collagenases/gelatinases), and MT1-MMP in canine X-linked Alport syndrome (XLAS). Kidney Int (2003) 63:1736-48. doi:10.1046/j.1523-1755.2003.00939.x
182. Vinge L, Lees GE, Nielsen R, Kashtan CE, Bahr A, Christensen EI. The effect of progressive glomerular disease on megalin-mediated endocytosis in the kidney. Nephrol Dial Transplant (2010) 25:2458-67. doi:10.1093/ndt/gfq044

183. Rare Disease UK. Experiences of Rare Diseases: An Insight from Patients and Families (2017). Available from: https://www.raredisease.org.uk/media/ 1594/rduk-family-report.pdf

184. European Medicines Agency. European Public Assessment Reports (2017). Available from:https://www.genomicsengland.co.uk/the-100000-genomes-project/ understanding-genomics/rare-disease-genomics/

185. Alport UK. (2017). Available from: http://www.alportuk.org

Conflict of Interest Statement: The authors declare that the research was conducted in the absence of any commercial or financial relationships that could be construed as a potential conflict of interest.

Copyright $\odot 2018$ Chew and Lennon. This is an open-access article distributed under the terms of the Creative Commons Attribution License (CC BY). The use, distribution or reproduction in other forums is permitted, provided the original author(s) and the copyright owner are credited and that the original publication in this journal is cited, in accordance with accepted academic practice. No use, distribution or reproduction is permitted which does not comply with these terms. 